\title{
Camphill Constituencies
}

Camphillers do not like to put people into categories. If you ask Camphillers about the distinctions that I will be discussing in this chapter-between villagers and coworkers, between employed coworkers and those who practice incomesharing and lifesharing, between those who reside full-time in Camphill and those who only spend their daytime hours there-you are likely to get into an argument. "Our dear friends, you might call them villagers," replied coworker Ruairidh von Stein when I asked him about the villager experience in Camphill, "I don't want to call them any names really, I hate titling, but anyway, they are our teachers." While the overcoming of categories is a sincere aspiration, it has yet to be fully realized in Camphill. Some Camphillers pay to be in Camphill and receive special support; some are paid to be there and to provide special support; some neither pay nor are paid. Often, the first group are called "villagers," the second "employees," and the third "coworkers," though there is much variation in terminology. This economic distinction coincides with a host of other distinctions about how people are invited to join the community, what roles they are encouraged or allowed to play, and how they exercise leadership. Sometimes, a subset of Camphillers is conflated with "the Camphill community" as a whole. My best guess is that Camphill can only transcend these distinctions by reflecting more explicitly about how they function currently. I offer this chapter as a contribution to that reflection.

Camphill's aspiration to overcome categorical thinking is entangled with the work of generational transition discussed in the previous chapter. As that chapter made clear, many Camphillers are thinking only or primarily about coworkers when they talk about generational differences. On the surface, that is where the generational problem lies: it is the long-term coworker group, not the other constituencies, that is still disproportionately composed of baby boomers. Yet this way of framing the problem ignores the radical diversification of Camphill constituencies that has occurred alongside the transition from baby boomers to Gen Xers and millennials. A successful generational transition will require not only the 
recruitment of more lifesharers from the millennial generation. It will also require the empowerment of Gen X and millennial villagers and employees who are already present in Camphill in large numbers. It might involve an expansion of leadership structures comparable to the transformation that occurred during the last years of Karl König's life. Just as he created structures that honored the new geographical diversity of Camphill, so today the movement needs to recognize the diversity of roles. The inner community, for example, might be renewed if it stopped assuming that a true "Camphiller" is a nondisabled adult with a spiritual connection to anthroposophy who lives full-time at Camphill and does not receive a salary. (Currently the inner community includes many members who do not fully fit this description because they have moved out of Camphill, but almost all of them have fit it sometime in the past.) Camphills are home to persons with disabilities who have lived there for decades and who serve as memory keepers and informal mentors to newcomers. Their mentoring gifts could be more deliberately cultivated. Likewise, many employees were drawn to Camphill because they resonated with its ideals, yet they are rarely asked to help hand Camphill to future generations.

In the most dynamic Camphill places today, the sense of communal belonging extends, not only to employees and to persons with special support needs, but to the community's neighbors. Lehenhof's neighbors cherish it for its bakery and its grocery store; the Bridge's for its café and walking paths. Camphill Callan in Ireland has played host to classes of young adults exploring environmentally sustainable, traditional building techniques. Parents and friends of Camphill Copake sponsor an array of fundraising cultural events. And Heartbeet has been part of Hardwick, Vermont's culinary renaissance. These places are full of people with a stake in Camphill's future.

Every generational transition involves a broadening of the definition of community. In Camphill's first transition, a founding circle with a common refugee experience took the brave step of opening their "inner community" to include anyone who shared their anthroposophical ideal of living in community with persons with disabilities. That generation extended the circle to include baby boomers with a much wider range of life experiences and ways of connecting to anthroposophy. But today, one assumption made in both of those transitions - that primary authority for transmitting Camphill's traditions from generation to generation belongs to lifesharing coworkers who are rooted in anthroposophy-has proven to be far too narrow. The Camphill Movement today includes hundreds of shortterm volunteers, nonresidential employees, extended families of residents, and nonprofit board members - to say nothing of the persons with disabilities themselves. A successful generational transition will empower all these people to fulfill Camphill's founding mission of bringing "renewal" to society as a whole-though perhaps it would be better to say that a deeper commitment to social renewal among Camphillers will ensure a successful transition. 


\section{STUDENTS AND VILLAGERS}

Persons with intellectual disabilities-sometimes referred to as "students" at Camphill schools and training colleges, and as "villagers" at villages, town communities, and elder communities-anchor Camphill life. Though they are not the outright majority of Camphillers, they are a strong plurality - at least, if one treats "young coworkers" with a planned departure date as a distinct category from "lifesharing coworkers" who have made an open-ended commitment. Many villagers have been part of Camphill for decades. If a Camphill place has a resident who has been a part of the community since its founding, that resident is almost certain to be an adult with special support needs. Students and villagers carry Camphill's memories, including memories of who is responsible for which household task or of who lived in the community ten or twenty years previously. The daily and seasonal rhythms of Camphill life are designed to help anchor the experience of persons with special needs: each day is broken into multiple short work shifts, with common break times and "rest hours," and festivals are celebrated in multisensory ways that remind everyone of the changing rhythms of nature. At most festivals and weekly religious rituals, villagers and students are the majority of participants. Many others are present primarily to help the villagers and students participate fully.

When Camphill places introduce themselves to the public, they often lead with the experience of villagers and students, putting the ideal of intentional community in a subordinate position. The website for Camphill Scotland asserts that "Camphill provides sector leading care services for people with learning disabilities and other support needs." ${ }^{2}$ Newton Dee's website says that they "offer a home, meaningful work and opportunities for personal development to adults with learning disabilities and other special needs." 3 And the Camphill Association of North America declares that "Camphill is an international movement of intentional communities designed to meet the needs of children, youth, and adults with developmental disabilities through a combination of community life, the arts and work on the land." 4

Yet not all Camphills describe themselves this way, and few are comfortable with the implication that Camphill is a place where people without disabilities work in service to people with disabilities. The mission statement of Camphill School Aberdeen, for example, leads with community and avoids any distinction based on ability: "To create a community where children and adults feel a sense of belonging, support and personal growth. A place where there is an inclusive, lifelong learning culture with an integrated approach to health, education and care." ${ }^{5}$ Camphill Village Kimberton Hills's statement also accents intentional community: "Camphill Village Kimberton Hills is a dynamic farming, gardening, and handcrafting intentional community that includes adults with developmental disabilities."

I do not mean to suggest that some Camphills understand themselves primarily as service providers for persons with disabilities and others view themselves as intentional communities. Most Camphills describe themselves in both ways, 
and there is no consistent correlation between a particular Camphill's language of self-description and its degree of adherence to the communal practices of incomesharing and lifesharing. Rather, the creative tension between identity as a service provider and as an intentional community defines Camphill precisely because it cannot be definitively resolved. Occasionally, Camphillers claim that Camphill began as an intentional community movement committed to social renewal, that it took up the work of curative education for accidental reasons, and that it could and perhaps should take up different tasks in the future. Such claims are unpersuasive because they drive a wedge between an imagined Camphill essence and the movement's actual history. They also betray the thousands of persons with disabilities who have devoted their whole lives to building up Camphill. Conversely, to describe Camphill as a service provider accountable only to the care needs of persons with disabilities is also a betrayal-for such persons have a right to contribute to society as well as a "need" to be "served." In an age that rejects the "institutionalization" of persons with disabilities, too much emphasis on Camphill's service dimension can, paradoxically, jeopardize the funding it receives from government agencies that are committed to providing persons with nonrestrictive, "community-based" care. As Veronika van Duin put it, "our biggest disaster has been to put the handicapped person into the center. They should have been in the periphery, not in the sense of exclusion, but because of them we've been able to make community. The moment we focus on them, we can't build community." 7

Because only about 15 percent of Camphill places today are schools, it can be easy to forget that Camphill's early work focused exclusively on care for children with special needs. This had a profound consequence for the history of the movement: although Camphill has always been built around the needs and experiences of persons with learning difficulties, in the early years it was only the nondisabled coworkers who made an open-ended commitment to be part of an ongoing Camphill "community." As things turned out, the coworkers were mistaken to imagine that they were the only ones who would spend their entire lifetimes in Camphill. Several of the first students went on to participate in village life. Yet the assumption that terms like "Camphiller" apply primarily to the nondisabled segment of the community and only secondarily to those with intellectual disabilities persisted in subtle and unintended ways. The widely read biographical compendia titled The Builders of Camphill and The Lives of Camphill, for example, do not feature the stories of any persons with intellectual disabilities. ${ }^{8}$ As these books make clear, the anthroposophical spirituality and shared refugee experience of the founders and early coworkers contributed as much to the emerging sense of "Camphillness" as did the presence of persons with intellectual disabilities. This blending of formative factors sets Camphill apart from the otherwise similar L'Arche movement, which has never sponsored schools and always placed the experiences of adults with intellectual disabilities at the center of its identity. In L'Arche, 
for example, persons with intellectual disabilities are called "core members," other people are called "assistants," and assistants rarely spend their whole lives with L'Arche. Camphill's hybrid sense of identity has sometimes created tension with social care authorities, who are rarely interested in any aspect of Camphill life except insofar as it contributes to the well-being of persons with intellectual disabilities. Yet the same hybridity lends credence to Camphill's claim not to be a network of institutions for social care, but rather an intentional community movement in which people of all abilities are equally valued, and all learn together what a nondisabling society might be like.

It is unlikely that a communal movement based on schools for children with special needs could arise today, at least not in the places where Camphill originated. The early Camphill participated in a cultural shift that helped the parents of children with intellectual disabilities recognize the human dignity of their children, and as a consequence most parents now want to keep those children at home with them. Society is now better, though far from perfect, at providing parents and mainstream schools with the tools they need to help children of all abilities flourish. The founding of Camphill schools slowed in the 1970 and virtually halted in the 1980s, with a few exceptions in postcommunist countries. Some Camphill schools have evolved into villages, others have endured in part by specializing in work with children with extraordinarily complex needs (usually those with both mental illness and intellectual disability) and in part by incorporating evergrowing numbers of day students. Because most of these schools have reduced their enrollments to accommodate more complex needs, the total number of students with disabilities who are part of the Camphill Movement is almost surely less today than forty years ago.

The children who first came to Camphill were a diverse and impressive bunch. Because disability was defined differently in 1939, many had diagnoses-such as epilepsy - that are no longer considered forms of intellectual disability. Some were referred to Camphill because of juvenile delinquency or because their parents were simply unable to manage aspects of their behavior. Most had been scarred by past experiences of rejection or failure, and many were surprised to learn just how much they could contribute to their new community.

The first student, Peter Bergel, was ten years old when he arrived at Kirkton House on May 10, 1939. His parents, like many of the founders, were German Jews who had escaped the Holocaust. The United States had accepted Bergel's parents as refugees but, bizarrely, forced them to leave their child behind in Europe. Anke Weihs recalled him as "barely able to speak, incessantly restless, his mind bent obsessionally on looking for cigarette cartons ... a thoroughly disconcerting new element in our lives." Thirty-six years later, he was a mainstay of the Botton Village community. The next student was not a child at all, but a thirty-six-year-old epileptic "whose convulsions were so violent and elemental that they could be heard from one end of the house to the other." Alistair Macmillan also arrived early on, 
cementing a partnership between his family and Camphill that ensured the survival and expansion of the movement.

Another early student, Athol Henry Byrne, born in 1937, arrived at Camphill School in 1952. He quickly developed strong connections to Camphill's founders and early leaders, among them Thomas Weihs and Hartmut von Jeetze, who instilled in him a "deep and lasting love for farming and for the land." After completing school, Byrne worked on several farms outside Camphill, then was recruited to help start the farm at the brand-new Camphill in Northern Ireland, Glencraig. He enjoyed this work so much that he asked to join the pioneering group for the other two villages in Northern Ireland, Mourne Grange and Clanabogan. In each case, he helped instill the Camphill ethos into employed or coworker farmers. Karl König's son described him as "a wonderful worker" with "great strength, and a deep love for the animals," and "by far the best hand-milker I have come across." Jens-Peter Linde, his cofarmer at Clanabogan, said that he never would have been able to start that farm without Byrne, both because of his vigor at digging postholes and stirring biodynamic preparations, and because "I learned from him how to be at peace with a cow: the head slightly angled, resting against her flank." Henry was also committed to the anthroposophical liturgy of the Christian Community. This gave him an opportunity to stretch himself: though he was ordinarily "not a man of many words," he learned the role of the right-hand priest's assistant, who "has to give the right answers." He could still perform this task perfectly on his deathbed, at age sixty-three. ${ }^{10}$

Byrne's pioneering efforts at Mourne Grange were complemented by those of David Austin Reid, an early student at Glencraig whose parents helped establish that community. After joining the founding group at Mourne Grange, Reid "informed himself of all the new buildings that were built" and was "especially conscious of safety aspects, constantly reminding us of the dangers of tractors and builders' equipment." Because of his safety consciousness, he was chosen as the community's "deputy fire officer," a role that allowed him to befriend local firefighters and thus deepen the new village's ties to its neighbors. He was also fond of taking his bicycle out into the neighborhood-a practice that one friend said was facilitated by his "very active guardian angel."

Other early students had more tragic destinies. In the early years of Glencraig, the community struggled greatly to gain the trust of their neighbors-some of whom spread rumors that they were Russian spies-and rejoiced when they attracted their first student. Robert was just five years old and fond of singing "Daisy, Daisy, give me your answer do," and soon four other students followed in his path. But little Robert died in his sleep just five months later, and it was "only through the tremendous help we received from close friends and his understanding Mother" that the fledgling community retained the trust of the local authorities. The Hermanus School in South Africa suffered a virtually identical early tragedy, when a boy named Robert died just before their first Advent Children's Service. ${ }^{12}$ 
When I asked coworkers to talk about the place of villagers in Camphill's future, they were unanimous in stressing the ways they make a deep experience of community possible for everyone in Camphill. "Adults with disabilities are the glue of the community,"13 said one; others identified them as "vital"14 and "the reasona necessity for this world." ${ }^{15}$ "They were always our teachers," explained another person. "They were the ones who gave us love. We aren't very good at loving each other as coworkers. ... It is the faithfulness that they have carried, for years and years we have worked alongside each other. If we were to be just a coworker community we wouldn't be able to survive." ${ }^{16}$ Even those, such as Veronika van Duin, who insisted that "Camphill's task was [never] the handicapped person, it was the human being," were quick to add that "the person with special needs has this amazing gift of equalizing everyone. You meet someone who has special needs and you forget yourself and you become a human being." ${ }^{17}$ At times these testimonies were tinged with romanticism, yet they clearly reflected a genuine experience: many coworkers struggle to imagine how a community would knit itself together emotionally if everyone had similar intellectual abilities. "Maybe they have cognitive learning disabilities, but we have learning disabilities in our emotions and in many things," explained music therapist Javier Gonzalez Roa after leading a class that I personally found more challenging than did some of the villagers in the room. "Normal people have problems to see other people. The guys with learning disabilities, at the moment they see you, they know how you are. ... They don't want you hiding yourself. ... So for me to work with them is so easy, because I just need to be myself." ${ }^{18}$ Another person pointed out that a diversity of abilities ensures that people do things together, because not everyone can simply do those things for themselves. When villagers go away for holiday, he observed, the rhythms disappeared, "because why should we all eat together sometimes if it is only coworkers? They can just make their own bread when they want, or cook something quick, do something else."19

Several Camphill places have taken deliberate steps to underscore their conviction that there is no essential distinction between persons with and without disabilities. Camphill Holywood, in Northern Ireland, has a single handbook for all community members, rather than a coworker handbook and a resident handbook. ${ }^{20}$ Newton Dee pairs every community participant, regardless of category, with a designated supervisor who helps them contribute to the well-being of the community. Newcomers are assigned supervisors upon arrival, and after about a year they have an opportunity to request someone specific if they prefer. "Generally," Jake Vollrath told me, "people will choose somebody because they want somebody who is going to reflect things back to them and actually challenge them to become better at their job." ${ }^{21}$

Most Camphillers are acutely aware that the language used to describe persons with special support needs can reinforce patterns of stigma and hierarchy, even when that language is intended to lower boundaries. Camphillers began using 
the term villager, for example, to avoid defining individuals primarily in terms of their clinical diagnoses. In theory, villager could include everyone who resides in a Camphill village. In practice, a villager is almost invariably someone entitled to receive special support and care, while a coworker is expected to provide that support and care. These terms are used even in some town communities that do not regard themselves as "villages" at all! Troubled by the way villager had become "just an alternative euphemism for talking about people with mental handicaps," the Loch Arthur village community repudiated the term soon after their founding in 1984. "To talk of 'villagers," Fran Clay explained, "is to fool oneself that one has found a solution that manages not to stereotype or subtly degrade the group you speak of-by now it is as much of a label as any other term." For the sake of transparency, they chose to stick with "people with handicaps" on those occasions when a term was necessary, freely admitting that they had not fully solved the problem. ${ }^{22}$ In my observation, most communities that refrain from using the term villagers wind up with another single-word euphemism: I have heard both friends and guys used in ways that signal that only persons with disabilities are included. When asked recently what terms they preferred, a group of persons with special support needs at Scottish Camphills opted for resident, tenant, student, member, day person, worker, day student, and human being, but none chose villager. ${ }^{23}$

Many Camphillers point to Rudolf Steiner's teachings on social therapy as an important source for this egalitarian ethos. "To me the core of social therapy is that we do not address the handicap," explained coworker Steffi Hagedorn at Camphill Solborg, "but we address the perfect core behind, the perfect human being that is behind there. ... When I talk to villagers I try to meet [them] as equals, in small glimpses." She tries to maintain a "humble attitude" that says "maybe they are handicapped, maybe they don't talk so well or walk so well, maybe they need a lot of help, but what can I learn? What do they teach me about the joy of life, about being present ... about accepting people?” This approach, she concluded, sets Camphill apart not only from mainstream social care but even from "other anthroposophic places where people come and work eight hours and go home."24

Writing in 1976, Peter Roth connected the full inclusion of persons with disabilities to another aspect of anthroposophy. "It is a prejudice of our intellectual times," he wrote, "to think that we, the 'normal' ones, need another culturalspiritual life than the handicapped adults, the villagers." This prejudice, he suggested, was a consequence of mainstream Christianity's rejection of the threefold view of humanity (as body, soul, and spirit) that Rudolf Steiner had restored. By affirming humanity's spiritual nature, anthroposophy could create a form of adult education that was not narrowly intellectual and thus truly inclusive. ${ }^{25}$

At some Camphill places, persons with learning difficulties have raised their own voices about practices that reinforce boundaries based on ability. Victor Alvez, who lived at Camphill Soltane for two years before his untimely death in 2001, began reversing roles at his entrance interview, when he brought a videocamera 
to tape his conversation with community founder Cornelius Pietzner. He also brought "the heart of an activist" to his participation in the community's morning meetings. "Have you noticed," he asked pointedly on one occasion, "that no one really listens when the companions [i.e., persons with disabilities] speak during our morning meetings the way they listen to the coworkers. We need to change that." Victor also contributed "a deep connection to Buddhism" to Camphill life, and frequently offered wise counsel to new coworkers struggling to connect with Camphill's spiritual practices. ${ }^{26}$

Many defenders of incomesharing and lifesharing are convinced that these are what make the full inclusion of persons with special support needs possible. The "community spirit" of Camphill, Jonas Hellbrandt stressed to me, is to "create a vocation for everybody in the world rather than [just] the so-called well-functioning normal people." Villagers should "be painters together with us, be farmers together with us, be musicians together with us." This requires equality, and "one of the most obvious ways of continuing to be equal is not having a financial difference between us." Similarly, when people live together, there is no difference in how much time they have to contribute to the community. The community can extend its "therapy" to everyone who lives there. ${ }^{27}$

At Camphill Vidaråsen, one community leader made this point with reference to a recent episode in that community's history, when the community rejected (in part) a consultant's proposal that they eliminate lifesharing. As soon as you start employing people "who are qualified in care, in social work," he explained, then the focus of the village shifts to the villagers' needs "rather than the villagers being able to contribute on an equal footing with everybody else [toward building] up the village together." It is a "contradiction in terms" to make the villagers the purpose of the community, "because the whole point of the Camphill community as far as I had been aware is that one creates a valid, vital environment for a range of different kinds of people into which those with special needs can be included." Indeed, the only reason Vidaråsen wasn't shut down with the other institutions in the 1980 os was that it made a convincing case that it was "a kind of inside-out integration." The parents of Vidaråsen's villagers rejected the consultant's recommendation because they did not want their children to be "treated as patients" but "as fellow citizens, as colleagues and friends." ${ }^{28}$

Nevertheless, there are few Camphill places today where everyone simply lives together on a basis of financial equality. In addition to the increasing numbers of nonresidential employees, many Camphills now include nonresidential students or "day program participants" - that is, adults who participate in Camphill workshops during the day but reside with family or in non-Camphill group homes. This is a change that has mostly occurred since the turn of the twenty-first century. When I visited Beaver Run in 2014, one teacher recalled that twenty years previously they had had just one day student. A decade later there were ten, then thirty-six day students alongside fifty-two residential students in 2014. Most of 
the people I spoke to identified this as the most significant recent change in the life of the community, which now felt like two distinct communities, one present on weekdays and another on weekends and evenings. Previously the whole community had taken a rest day on Thursdays, then observed a fairly intense Saturday culminating in Bible evening; now it followed the conventional five-day work week, even though this rhythm was difficult for many of the children. It became more difficult for the community to celebrate the traditional Camphill festivals, which often fell on days when nonresidential students were not present. Previously, class teachers had operated with much autonomy and freedom; now they followed detailed "individualized education plans" for each student. Because the students had increasingly complex needs, many of them worked one-on-one with a young coworker for much of the day, disrupting the therapeutic power of the classroom community. ${ }^{29}$ And most visibly, the nonresidential students shattered the boundary that had once separated Beaver Run from the larger society. "You have twenty-five school buses coming in every morning," observed Guy Alma. "The outside world flows through the place, even visually, when you see that yellow line of buses going up the hill."30

I felt a similar influx of influences from the larger society at Camphill Tiphereth, which hosts dozens of day participants in addition to the residents of its three houses. Many of these people participate in Tiphereth's community composting program, which collects yard waste and food scraps from homes and businesses in southern Edinburgh, then trucks them up to a former quarry high on a hill above the city. The composters are continually on the go in and out of the city, which remains visible to them as they work. Other day program participants engage in crafts and therapeutic workshops in the large building that also hosts Tiphereth's offices. Javier Gonzalez Roa stressed that the day program participants derive significant benefits from spending their days in a community setting that is somewhat detached from the rest of society. "This lovely Camphill world is really good for their soul," because it gives them a break from "the TV and all these distractions." ${ }^{31}$

Even as some Camphills open themselves to nonresidential students and adults with special needs, there are other Camphills where persons with learning difficulties constitute the entirety of the residential community. England's Camphill Village Trust, for example, has phased out lifesharing in most of its communities. Though many coworkers (and others) perceive this as the end of intentional community and a return to the old institutional model of care, the fact is that the villagers are still doing the hard work of creating life together. I got a brief glimpse of this new model of Camphill community when I visited the Croft, a small town community located an hour's drive from Botton Village. After attending a church service in which several persons with disabilities played leading roles, I stopped off at one of the residences. It was much messier than the typical Camphill home, and it seemed to have a more chaotic schedule, as some residents were eating breakfast individually rather than as a group. The materials displayed 
on the walls, and the slogans on people's T-shirts, suggested that there was less anthroposophical influence and more exposure to popular culture than in other Camphills. But what I noticed most strongly was the sense of ownership exhibited by the people who lived there: they were clearly proud to show a visitor the home that they had created. They also had stronger verbal skills and more capacity to perform personal care tasks than many of the profoundly impaired adults who live in traditional Camphill villages.

My perception of the Croft was echoed by a staffperson at Sólheimar, an anthroposophical community for people with special needs founded just prior to Camphill. For many years, all of Sólheimar's nondisabled staff lived offsite, and today they live in the village but in separate homes from the persons with disabilities. Coworkers, he said, "tend to forget, we are so self-centered, we think we are carrying the community, but at the end of the day it is the people with disabilities who are-they have been here $24 / 7$ for decades." Still, he cautioned against generalizing too much from this experience. Many of Sólheimar's villagers had come as children and lived there for as many as sixty years, building up "a certain kind of culture." Now they are being replaced by a younger generation whose "complexity of ... disabilities is much greater than in previous years." ${ }^{32}$

The increasingly profound impairments of many villagers create a challenge (and an opportunity) for all Camphills, regardless of their stance on incomesharing and lifesharing. The shift is a consequence of social care policy, which discourages the placement of persons in large or even midsized residential settings if they have any capacity to live autonomously. The relatively "high-functioning" students and villagers who built up Camphill in the early years would likely not be allowed to live there today, unless they had the wealth to pay Camphill's fees without government support. While many social workers assume that the "right" villager for Camphill is a person with multiple and complex needs, many coworkers think it is someone who is able to make an active contribution to village life. "There is a certain group of people with special needs that we are fit for as a community," observed one coworker. "People who can work in workshops. People who don't need very specialistic psychological care." And it "may be a challenge in the future to find [such] villagers." ${ }_{33}$

Of all the Camphills I have visited, Camphill Glencraig in Northern Ireland had probably gone the furthest down the path of redefining itself as a place for persons with extraordinarily complex needs. The change "hasn't always been something which has been agreed by the rest of the community," explained Vincent Reynolds, but it did honor a timeworn Camphill principle: "This is what was said by Dr. König in the beginning, that the aim is to meet the needs." Again and again, the social care authorities came to Glencraig with children with "very challenging behavior" who had already been excluded from other schools for special needs children. The arrival of such children provoked a backlash from some coworkers, both because they lacked the training needed to be genuinely helpful and because 
one-on-one care for individual children did not fit with their image of community life. "You have to be really engaged with these young people. You have to be following them around all the time. It can also be very demanding when you are just observing someone and nothing appears to happen." Still, the reality was that if they refused to accept such children they wouldn't have a school at all. ${ }^{34}$ So the community has brought in employees able to meet the children's needs. At the time of my visit in 2013, they were setting up a new house to accommodate a single girl who required the support of multiple employed caregivers twenty-four hours a day. The community was just beginning to imagine how they might give the girl a genuine sense of community connection.

At many Camphills, the challenges associated with the increasingly complex needs of new villagers are coupled with those associated with the aging of villagers who arrived decades ago. "There seem to be more physical limitations," reported the coworker Jake Vollrath at Newton Dee. Previously, "we did quite hard physical work, and now the work isn't quite as rigorous physically, but we have to find new ways to provide meaningful work for everyone." 35

The fact that social care authorities are often willing to place only profoundly impaired persons at Camphill highlights one of the most vexing boundaries within the movement: persons with and without intellectual disabilities join Camphill communities through vastly different processes. Those with disabilities can join Camphill only if someone-usually the government, sometimes a family member - can pay a hefty participation fee. Those without disabilities can join for free, if they can convince the community that they are capable of supporting persons with disabilities (or, in some cases, that they have agricultural, medical, or artistic skills needed by the community). There is no path in for people whose support needs are so minimal that they are not eligible for government benefits, but whose disabilities or other life challenges limit their capacity to provide therapeutic support to others. Yet such persons, who would have no other role except to participate in the life of the community, could bring a great deal to Camphill. I had the privilege of witnessing this during my first summer at Camphill Village Minnesota. A very mildly disabled young man who had grown up as a staff kid at Camphill Minnesota, then attended a Camphill training college as a student, was back for the summer to reconnect with his parents and Minnesota friends. Like me, he was assigned regular workshifts, but none of the therapeutic tasks ordinarily given to coworkers. He quickly became my beacon for Camphill life, someone who entered into each task with enthusiastic joy and attention to the emotional dynamics of everyone else present.

The legacy of Camphill's beginnings, in which the enduring "community" consisted of the nondisabled coworkers who taught in the school, still lingers in many ways. It is evident in the movement's newsletters, which only occasionally publish the words of individuals with learning difficulties. Virtually every issue of the Camphill Correspondence, the newsletter since 1975, contains at least one coworker obituary, and often three or more articles devoted to the life of a single notable 
coworker. The lives of villagers are also remembered, but only sporadically, and almost never with more than a single article.

Many Camphills also maintain boundaries based on disabilities through their decision-making structures. Few of the nonprofit boards that provide legal governance for Camphill places include either villagers or other persons with intellectual disabilities (such as leaders in national self-advocacy organizations). It is common for Camphill places to have "management teams" composed entirely of coworkers, or with a mix of coworkers and employees but no persons with intellectual disabilities. Most day-to-day decisions are made by committees with specific mandates, such as assigning individual work shifts or ensuring that each house community is functioning smoothly. Since these committees operate by consensus, they could easily make room for members who are able to understand some of their decisions but not all. Yet they rarely include persons with special support needs, with the frequent exception of committees whose task is to prepare for festival celebrations. In many Camphill places, the primary venue for villager participation in decision making is the "village meeting" - a gathering of all residents in which any person can bring a concern or request to the community. These meetings have succeeded at giving all villagers the chance to shape the places where they live. But maintaining that success is a delicate balance. If coworkers fail to attend, then concerns expressed by villagers may not be heard by the people best able to address them, but if too many coworkers participate, their voices may drown out the less confident voices of the villagers. ${ }^{36}$

I have received a variety of answers when I have asked Camphill coworkers and board members about the absence of villagers in decision-making roles. Placing a villager on a decision-making committee "can sometimes be a bit false," one person pointed out, because "it doesn't actually mean that they are being included in the decision-making process." ${ }^{77}$ Some have pointed out that nonverbal and other profoundly impaired villagers would not be able to play such roles, and that it would not be fair to give additional power to the others. That's a valid concern but not insurmountable, especially in a consensus system where the coworkers would doubtless take extra care to represent the needs of villagers who were unable to participate on their own behalf. Some have said that a small number of villagers can and do participate in decision making, but that this is simply not the best gift that most have to offer the community. That's probably true, and compared to many communal movements Camphill benefits from having a large number of people who cherish community but are not obsessed with governance. Still, much the same could be said of coworkers: many came to Camphill in order to pursue a particular craft or therapeutic vocation, but actually spend much of their time in decision-making committees out of a sense of duty to the community. Why shouldn't the same duty apply to persons with disabilities?

Many coworkers responded to such interview questions by agreeing emphatically with my underlying concern. "I would like to see them in much more prominent roles," replied Ruairidh von Stein. "I don't think it is right to make 
decisions on behalf of residents, villagers. . . They are part of our shared future." ${ }^{8}$ Camphill, one person told me, is "more and more, waking up and wanting to take into account the issue of civil rights" for persons with intellectual disabilities. She pointed out that the practice of intentional community is inherently complex, because every community member gives up some of their individual rights when they accept the shared rhythms of the community. But too often Camphill fails to do the hard work needed to maximize individual control over such decisions as dietary preferences. The challenge, she said, is "how to help the people we are supporting to actually begin to develop the muscle to understand their rights and to exercise them meaningfully." ${ }^{9}$ Her colleague added that this is especially important because so many villagers have acquiesced to their parents' preference that they be in Camphill rather than making a fully volitional choice. And so their community has worked with an organization called the Council for Quality and Leadership to learn a practice of "reliable interviewing," so as to ask each villager, of whatever ability, to make an authentic choice each year about whether to continue in Camphill..$^{\circ}$ Other Camphill places have organized "self-advocacy" groups for villagers, sometimes giving them responsibility for recreational spaces within the village. The results can be unsettling for persons devoted to Camphill tradition: In one village tour, I was shown a "self-advocacy" room that included a bank of computers, a large-screen television, and other amenities previously shunned by Camphill. Such experiences might be a sign that Camphill is not doing enough to recruit villagers who truly want the alternative lifestyle of intentional community, or they might indicate that villagers truly cherish Camphill life but don't think it is quite as antithetical to the social mainstream as coworkers have assumed. Either way, they should not be ignored.

Often, this means taking decision making to the level of each individual. A coworker at Camphill Heartbeet told me that they actually do have a villager on their board of directors, and have since the beginning. But she acknowledged that they are not represented on the community's working groups, partly because "severe anxiety" is one of the impairments for many of the people in the community. "My job is to help create simple, meaningful rhythms where their anxiety does not have to be triggered." That means that instead of inviting people onto decision-making committees, she needs to be willing to enter into one-on-one agreements that are truly binding on her. "If a friend wants me not to use certain language in a conversation with them, then I won't use that language." She concluded that "inclusion means that I am not trying to peg someone else's needs into what I think needs should be." ${ }^{41}$

One important marker of the inclusive ethos is the recognition of villagers' sexual identities and needs. Increasingly, Camphills actively seek to facilitate safe and appropriate sexual expression for everyone who lives in Camphill. At Heartbeet, one young couple with learning difficulties was guided through the process of dating, engagement, and marriage, and now maintain a semi-independent apartment 
as a married couple within the community. Vidaråsen, working with outside specialists in sexuality, has set up support groups for men, women, and couples. They've also worked to identify "borderline problematic sexual behavior," before it creates the sort of problem that would lead to the expulsion of an individual from the community. The truth is that sexual abuse is part of the history of more than one Camphill, and it sometimes involves perpetrators with intellectual disabilities and victims who are persons with intellectual disabilities or staff children. So, even as Camphills have tried to be more affirming of sexuality, they have also enacted safeguarding practices that can sharpen divides within communities, such as the policy that coworker families with young children do not share bathrooms or other intimate living spaces with villagers. ${ }^{42}$

A final way in which villagers are distinguished from other Camphillers has to do with the practice of anthroposophy, and of religious services inspired by anthroposophy. An important anthroposophical principle is that "freedom" is the guiding principle in the spiritual life. Most Camphills are careful to ensure that no person, coworker or villager, is required to attend religious services. Yet in practice many villagers do attend, and most young coworkers do not, and newcomers to the community easily discern that this is the unspoken expectation. Even villagers who identify strongly with their Jewish heritage participate in religious services with strong Christian content, and are not necessarily offered the transportation or other support they might need to participate in Jewish rituals. At the same time, villagers who manifest a profound devotion to the public practice of anthroposophy are rarely invited to encounter its more esoteric expression by, for example, joining the Camphill inner community or attending an anthroposophical study group. Many Camphill places offer the "Festival of Offering," a ritual that is designed to be led by specially trained laypeople known as "service holders." Villagers are seldom asked to be service holders, even in places where they are the most faithful participants in the service. It is more common for villagers to serve as assistants to Christian Community priests who preside at the Act of Consecration of Man, but that can happen only in places with resident or visiting priests. Of course, it is possible that some villagers are participating in the esoteric work of anthroposophy in ways that are too subtle for me to observe. As one long-time coworker told me, "saying the Our Father every night is certainly esoteric work." 43

Camphill's categorical distinctions come closest to dissolving in its festival life. In keeping with the indications of Rudolf Steiner, Camphill celebrates seasonal festivals in ways that blend Christian tradition with nature spirituality. Christmas, Easter, St. John's, and Michaelmas-days that correspond roughly to the solstices and equinoxes - are the most important festivals. A Christmas celebration may include meditative reflections on each of the "Twelve Holy Nights," while St. John's features a massive bonfire. Michaelmas uses the story of Michael's defeat of the dragon to reflect on ways of overcoming evil. Camphillers spend weeks preparing for each festival, often practicing musical or dramatic performances or involving 
people of all abilities in the creation of works of art, such as a giant paper lantern in the form of a dragon.

Camphill's festival culture has helped it include people of diverse abilities in conferences that bring people together on a regional or international basis. Even when a conference coincides with a decision-making meeting that is not fully inclusive, villagers and students are often invited to come along. In many conferences, participants are divided into artistic groups (devoted to singing, drama, eurythmy, sculpture, poetry, and other forms) that meet once or twice a day in order to develop a performance or exhibit to be shared with the entire gathering. As early as 1976, the German villages designed a conference especially for villagers. Each day began with a lecture with such thematic titles as "Sleeping and Waking" or "Doing and Perceiving," followed by a conversation in which participants practiced listening deeply to one another. As Regine Blockhuys wrote: "The villagers contributed in a wonderful way out of their personal experience, or often out of the sphere of their work or sometimes quite from above, giving the talk a direction which made it a deep and moving experience for all. Some spoke more often at the beginning and learned to hold back, others surprised us by speaking exactly to the point reached in the talk after they had been silent for long." Participants also had an opportunity to display products created in their workshops to their new friends, and each evening they rehearsed a play together. Many of them praised the experience in terms that underscored its value: "I never experienced such a lovely thing as this conference!" 44

The German villagers conference may have inspired a similar gathering at Blair Drummond in Scotland in August 1976. Once again, its structure mirrored that of conferences for coworkers, with serious discussions intermingled with prayers, singing, and artistic activities. The first discussion was about work and money, explained observer Erika Opitz, and participants affirmed the centrality of meaningful work to their sense of identity. "I know it has to be done.' 'It is essential.' 'It is done for others and with others.' 'I feel well when I have done well." Later, the participants reflected on their motives for living in Camphill stressing that "there I can be myself"; that in community "I can help others, care for others"; and that community life had helped them break out of isolation and enjoy being with others. Writing in the Camphill newsletter, one participant observed that "It was very fruitful that we could all talk together without the distinction of villager and co-worker, all equal, feeling that we discussed what it means to live in Camphill." 45

I experienced the same spirit at a Whitsun celebration that the German Camphills hosted for the international movement in 2018. This was designed as an inclusive festival in which villagers, coworkers, employees, family members, board members, and neighbors could participate simply as human beings, without regard to their diverse roles. From the beginning, the planning process reached beyond Camphill, and many of the sessions were held at Lautenbach, a village community that is rooted in anthroposophy but not formally part of the Camphill 
Movement. Each evening featured a public lecture, while the daytime was devoted to artistic pursuits. The whole thing culminated in a parade led by a brass band and featuring massive, newly made puppets and banners displaying inspirational quotes in many languages. Participants of all abilities performed in a series of plays, and a troupe of clowns who were newly equipped with red noses interrupted the proceedings with bumbling hilarity. It was a foretaste of the social renewal that Camphill aspires to bring to the entire world.

Ultimately, the inclusion and empowerment of students and villagers is what will best equip Camphill to plant seeds of social renewal beyond its own boundaries. "Every year," Camphill founder Thomas Weihs announced in his 1975 annual report on Camphill School, "Camphill sends out about one hundred emissaries. About a third of them are the handicapped and disturbed youngsters who have been educated, helped, and guided to grow up into freedom and dignity" ${ }^{46}$ In the same year, a person at Newton Dee, Margarete von Freeden, observed that "our Villagers have a great number of friends in Bieldside and around. On a fine Saturday or Sunday a stream of 'Newton Dee-ers' can be seen walking to and from Aberdeen. In shops or neighbours' front gardens you can be asked with deep concern about matters you thought only the inhabitants of Newton Dee knew of." ${ }^{47}$ This dynamic has intensified as the larger society has become inclusive of persons with disabilities and as social care bureaucracies have expanded, enabling students and villagers to introduce their social workers or volunteer "buddies" into contact with Camphill. If the modern quest for authentic community is to move from the cultural fringe to the center, perhaps it will be persons with intellectual disabilities who make it happen.

\section{LIFESHARING COWORKERS}

Students and villagers represent one of the great continuities in Camphill. They have always been central to Camphill life, even though the exact meaning of that centrality has shifted over time. Lifesharing coworkers, by contrast, represent a great change. When Camphill began, it was possible to use the term Camphill community when one was referring only to these people, but today they are probably the smallest of the major constituencies within Camphill.

With the phrase lifesharing coworkers, I refer to people who live full-time in Camphill communities, do not have intellectual disabilities or comparable care needs, have an open-ended commitment to living in Camphill for the foreseeable future, and do not receive salaries or wages commensurate with the care work they perform. This definition is deliberately vague, for there is no sharp boundary between lifesharing coworkers and other groups of Camphillers. In the United States and Scotland, lifesharing coworkers often also practice incomesharing, albeit with modifications designed to give them more freedom to leave Camphill at midcareer or in retirement. In continental Europe and Canada, it is more common 
for lifesharers to receive formal salaries designed on egalitarian principles, with the most experienced coworkers receiving only slightly more pay than newcomers. Some Camphill places make a strong distinction between lifesharers who live in the community and employees who do not; others insist that there is no distinction, because everyone shares their life in one way or another.

Lifesharing coworkers may also be referred to as "vocational coworkers," because they have chosen Camphill as their vocation, at least for a significant portion of their adulthood. Those who share incomes may be called "trust money coworkers," referring to the system in which coworkers "trust" the community to provide for their needs. Typically, each individual or family identifies needs for the coming year, and then the coworker group discerns whether they are able to accommodate all requests. Unlike participants in some service communities, trust money coworkers do not necessarily live near the poverty level. They occupy beautiful homes, eat organic and biodynamic food, send their children to Waldorf or other private schools, and-at some communities-take international vacations on a yearly basis. The guiding value is not sacrifice or even simplicity; it is that human labor should not be reduced to a commodity. From the Camphill perspective, all human beings have a right to offer their best gifts freely to other people, and to have their needs met regardless of the economic value of their gifts.

Many people regard the declining number of lifesharing coworkers as Camphill's greatest challenge. "I think our biggest [challenge] is bringing young people here so they can help carry this into the future," Leslie Fish told me. "Because the large majority of us are heading down the retirement road soon. And we don't have a good core of young people who are going to carry this in the future." ${ }^{88}$ In the 1970s, one baby boomer recalled, "many people came to Camphill around the world ... and met something very strongly and committed themselves to that work. I don't see that happening so much anymore." ${ }^{49}$ Another coworker, Christoph Hanni, echoed that thirty years ago Camphill School Aberdeen "was the generator of coworkers," a place where young people could begin their life in Camphill and then move on to greater responsibility in a newer Camphill place. "That kind of kept the Camphill Movement going"-and now it "has totally gone."50

Some view the decline in lifesharing coworkers as tantamount to Camphill's demise. This is the lament of one person who migrated as a "refugee" from Holland to Scotland when the former country abandoned both incomesharing and a horizontal decision-making structure, only to see similar changes in British Camphills. "If you employ more and more people who don't really know what it is about and who are not interested in learning more about it," Marjan Sikkel said, "then it just disappears because we get older and we die and it is gone." "It "I'm not sure it qualifies for being a Camphill anymore," complained one coworker of a place where he had lived for sixteen years before it had abandoned lifesharing..$^{52}$ At a more traditional Camphill in Norway, coworker Steffi Hagedorn echoed this sentiment: "social therapy is all about creating a social organism between us.... It 
is not me being the therapist and the other one being the patient, but it is a social organism that is therapeutic for everybody involved. And how you do that when half of you are paid by the minute and half actually live there?" 53

Most Camphillers who worry that the decline in lifesharing might spell the end of the movement see this as a gradual process. One explained that with the shift from lifesharing to conventional employment, it is tempting to see persons with special needs as "service recipients." This in turn creates a "wrong footing" for intentional community, which is all about "interacting and being shaped by other people ... including people with disabilities. They are not a separate stream, they are also people who help me, annoy me, inspire me, make me a better person, and I also can help them because I can see things that they are weak in and I can support them. So it is that true interaction with those disabled people, that's the kind of schooling path of Camphill." ${ }^{54}$ Guy Alma of Beaver Run acknowledged that he still feels a sense of "Camphill-ness" in places run entirely by nonresidential employees, but wonders if "that tangible presence will be there one or two generations hence." The crucial factor underlying Camphill identity for coworkers, he explained, is the experience of "living with individuals with developmental disabilities day in and day out.... That is the seed which everything else grows from." Currently, many of the employed managers did have that experience before moving out of Camphill, and so "the matrix is still there for that grace to touch down," but when that ceases to be the case, "I think you'll have echoes in the architecture and the rest of it, but I don't think that presence will be tangibly there anymore." ${ }_{55}$

A number of factors contribute to the decline in lifesharing coworkers. In Germany, Switzerland, and France, incomesharing is technically illegal: all people are guaranteed a salary commensurate with the job tasks they perform. Because this change was implemented early in Camphill's history, when the movement was otherwise thriving, some of those communities were able to preserve the incomesharing spirit by creating "social funds" in which coworkers voluntarily pooled their salaries. But many of these systems declined over the years. "They found," said one observer, "that there was an unfortunately close relationship between the amount you were putting in freely and the amount you were taking out." 56

In Great Britain, the employment laws are more flexible when it comes to longterm volunteers, but many Camphill boards have nevertheless concluded that incomesharing and lifesharing are not legally feasible. Incomesharing makes it more difficult to be transparent about how government funds are spent; lifesharing complicates the work of safeguarding villagers from abuse. Early in the twentyfirst century the Camphill Village Trust, which operates most villages and town communities in England, began transitioning individual communities to a model based on conventional employment; subsequently they imposed this as a universal policy. Other communities, most recently Ballytobin in Ireland, have been forced to abandon lifesharing by social care authorities in the wake of reports of abuse. "The traditional Camphill model of coworkers running a community has almost 
completely disappeared" in England and Wales, one community founder told me in 2013. "You could count on the fingers of one hand in this country communities which are substantially run by coworkers." 57

The ethos of lifesharing remains strong in several parts of the Camphill world, among them several of the Scottish communities, most of the communities in the United States, the entirety of Norway's Camphill Village Trust, and many German communities. Yet even these places find it more and more difficult to recruit lifesharers with an open-ended commitment, or to persuade young coworkers to take on a more permanent commitment.

One reason is the increasing bureaucratization of social care. Coworkers who long simply to share their lives often resent having to fill out detailed reports on the adults with whom they live, and to comply with household regulations designed for large institutions. For instance, I have seen Camphill kitchens in which the posted regulations indicate that people cooking rice must repeatedly check its temperature to ensure that it complies with a government-mandated standard. "It becomes so difficult to have a normal lifesharing," lamented Tobias Pedersen, a former coworker who was an employee at the time of our interview and has since taken a position with the Biodynamic Agriculture Association of Ireland. "People are exhausted. They can't do it. They get burnout." As an employee, Tobias still had to comply with bureaucratic regulations, but these were no longer coupled with the very different burden of being emotionally present twenty-four hours a day. "I can hopefully recharge my batteries and have a life outside of Camphill." Still, "it is definitely a sadness. There is something missing as a result." ${ }^{8} 8$ Another Camphiller said that when he tried to compose a job description for a lifesharing house coordinator, simply listing all the tasks that they are legally required to perform, others in the community rebelled. "Nobody liked it. They were terrified by it. . . . They said nobody's ever going to apply for that." 59

As the numbers of lifesharing coworkers have declined, some Camphills have sought to protect the ethos of lifesharing by restricting certain roles, such as management and house coordination, to lifesharers. "We have made a conscious choice," explained Jake Vollrath of Newton Dee, "that we want to make sure that the intentional community members who are living in are the ones who are really managing Newton Dee. . . . Because when you live in the community, your ... awareness of the needs of the whole community can be quite drastically different. And we want to be able to carry that ourselves." This commitment has led to some compromises in the community's egalitarianism. The circle of house coordinators, for example, has no overarching manager because they are all lifesharers, while the workshop coordinators, most of whom are employees, report to an individual manager, who is a lifesharer. ${ }^{60}$ Similarly, instead of appointing an executive director, Beaver Run vests management authority in a "Beaver Run Circle" that is open only to lifesharers with at least three years of community experience, an open-ended commitment to remaining at Beaver Run, and a personal connection 
to anthroposophy. People involved in the Beaver Run Circle consistently testified that its restriction has helped the community maintain a coherent vision. ${ }^{61}$ Beaver Run has also mandated that its many employees report to supervisors who are themselves coworkers-and who have been properly trained for their supervisory role. "The attempt is to penetrate every area of life with anthroposophy," Guy Alma explained. "And you can only really do that if you have people who are seasoned coworkers from the village who are trying to work out of that orientation ... who at the same time actually have some mastery of the more prosaic day-to-day things." ${ }^{2}$

The paradoxical consequence of policies that restrict management tasks to lifesharers is that lifesharers have less time for the daily activities-cooking and cleaning, participating in workshops, offering therapies, and joining in festivals and cultural events - that constitute lifesharing. A typical house coordinator, one coworker told me, might have weekly one-on-one supervision meetings with each young coworker in their house, weekly meetings with the other house coordinators, biweekly meetings with the central leadership body, and ad hoc meetings called to respond to specific challenges. "I would say about half the time maybe could be in all those different kinds of meetings." ${ }^{63}$ In many cases, lifesharers have taken time away from community life to earn degrees or certificates that will qualify them to serve as managers who interact with social care or educational authorities. When Beaver Run needed a new director of programs for its school, for example, they identified a lifesharing coworker who was a great fit for the role but not yet formally qualified. They paid for him to pursue a master's degree in special education and hired a special education director from a nearby school system to perform the role on an interim basis. This added to the workload of another lifesharer, who was called upon to supervise the interim employee. Ultimately, the process was a great success, but it represented a radical cultural shift from the days in which just one person handled all of Beaver Run's interactions with the educational authorities. ${ }^{64}$

Most Camphills have evolved economic structures that make small compromises with employment law and the social care establishment, while preserving the ethos of lifesharing. Many of these compromises seek to guarantee the economic security of lifesharing coworkers who leave Camphill, both by offering "leaving money" commensurate with years of service and by paying in to government pension plans. These policies recognize that many coworkers have a long-term but not lifelong commitment. They reassure care authorities who wish to know exactly how their funds will be spent, and coworkers who are not confident that Camphill itself is committed to them. Another compromise is the creation of "economic fellowships" for Camphill coworkers who receive salaries as mandated by government but want to separate their work from their income. At Solborg and other Norwegian Camphills, for example, brand-new coworkers receive housing, food, a small stipend (known as "pocket money") and a guaranteed level of leaving money. After they've stayed for a certain period, they are invited to join both the 
village council (the governing body) and an "economic fellowship" that provides them with additional funds based on need. Members gather every two or three weeks to share both their monetary needs and their needs for time away from the community. "That group can decide amongst themselves if they want to give that money for something you need or give that time to do something, " explained one participant. ${ }^{65}$ Even so, some members of the community long for a deeper sense of economic community. As Steffi Hagedorn explained, "We share our budgets, we share our needs, and we share the money, but we do not yet share our accounts. We don't actually tell each other how we have used the money."66

When I spoke to younger lifesharing coworkers (as distinct from "young coworkers" with a short-term commitment), most articulated a balanced set of desires. On the one hand, they had chosen Camphill because of the way it separated work from income: "We all do work because it is needed," said Steffi Hagedorn, "and we do what we can, we give all we have, and then our needs will be covered." If Camphill were just a job, they said, they might choose a different job. ${ }^{67}$ On the other hand, they stressed that the role needs to evolve in order to retain its appeal and viability. While previous generations of coworkers often felt they "worked for free" and with a lifetime commitment, said Jonas Hellbrandt at Newton Dee, "the traditional coworker model for a generation like mine is more a recognition that we work under a very different salary structure, a needs-based structure. I don't think we as a generation feel we work for free." What's more, it involves a commitment to "this lifestyle for the foreseeable future," but not necessarily for a lifetime. ${ }^{68}$

This balanced approach, coupled with the influx of "refugees" from Camphill places that have abandoned lifesharing, has stabilized the constituency of lifesharing coworkers at many Camphill places. Worldwide, hundreds of millennials are living the Camphill coworker life in much the same manner as previous generations. Yet there is, to my knowledge, no Camphill place that is dominated by lifesharing coworkers to the degree that virtually all Camphills were dominated a generation ago. I have not visited any Camphill place in which all workshop leaders were residential coworkers. Whether the group of lifesharing coworkers is stable or shrinking, they must shape Camphill's future in partnership with others.

\section{YOUNG COWORKERS}

Unlike lifesharing coworkers, so-called "young coworkers" have remained a stable component of the Camphill organism. Like other coworkers, "young coworkers" are people without intellectual disabilities who live full-time in Camphill communities, participate in household life, workshops, festivals, and therapies alongside other Camphillers, have their economic needs met, and receive no formal salaries. The key difference is that they commit to only a fixed term of participation in Camphill. The most common pattern is for young coworkers to join Camphill for a year of service, often a "gap year" between high school and university, or a 
postcollege volunteer year. Most young coworkers choose Camphill places outside their home countries. At least since the 1960s, Camphill communities have advertised through nonanthroposophical networks designed to promote international volunteering, and these networks have brought volunteers whose primary motivation may be to see the world or to explore the possibility of a career working with persons with special support needs. Other young coworkers come from anthroposophical families or are graduates of Waldorf schools; these people may have chosen Camphill because they want to deepen their connection to anthroposophy or simply because the anthroposophical milieu is comfortable for them.

Two of the young coworkers I met at Glencraig illustrate the range of paths these young people take to Camphill. One said that her process was "quite spontaneous." She had wanted to go abroad, and so she applied to a Red Cross project in England. When that fell through, a friend of her mother's whose children had attended Waldorf schools introduced her to another young woman who had done a gap year at Glencraig. She applied in late spring, got approved, then had to get approval from a German organization so that it would be an "official" volunteer year. When she arrived in Glencraig, she was surprised by "how big it was and also how beautiful. I really liked the sea." She had a great experience, made lots of friends, and got "brilliant references" from the teachers with whom she worked. Yet she never seriously considered a long-term commitment to Camphill, which she described as a "bit like a bubble": beautiful, good for the villagers, but socially isolated and demanding for long-term coworkers. ${ }^{69}$ The other young coworker had deeper Camphill roots: his father was a Waldorf teacher, his severely epileptic sister had been a student in a Camphill community for eight or nine years, and he himself had attended Waldorf schools his entire life. He also came to Glencraig intending to stay for one year, but when he heard about the opportunity to pursue a multiyear seminar, he embraced it..$^{\circ}$

Both of these young people were German, as were the majority of young coworkers until quite recently. Until recently, German law mandated military service for all men but allowed them to substitute domestic and international volunteering. This created a culture of gap-year volunteering that applied equally to women, who were not subject to the conscription law, and has persisted since conscription was placed in abeyance in 2011. Since 2011 the distribution of nationalities among young coworkers has diversified, though Germans are still the largest group. The United States does not have a vigorous culture of gap-year volunteering, but recent college graduates may come to Camphill through Americorps or similar programs. Some U.S. Camphills, recognizing that college graduates are more mature and more likely to make a long-term commitment to Camphill, actively discourage volunteers who are under twenty years old. Interest in Waldorf education and other anthroposophical initiatives has increased in China and South Korea, inspiring young people from those nations to come to Camphill in hopes of gaining the skills they will need to plant new initiatives back at home. Restrictive immigration 
laws in North America and Europe make it difficult for Camphills to obtain visas for volunteers from Africa and other developing nations, though they regularly receive promising applications from these places.

While many Camphills use the term young coworker exclusively for people in their first year at Camphill, I am also including so-called seminarists and BA students who participate in multiyear training programs. Camphill School Aberdeen inaugurated its first "seminar in curative education" in 1949, and it served as a model for the seminars in curative education (at Camphill schools) or social therapy (at Camphill villages) offered by most of the larger Camphill places ever since. These immersive and experiential seminars are structured similarly to the training courses that prepare people for other vocations connected to anthroposophy, such as Waldorf teaching, biodynamic farming, eurythmy, or the Christian Community priesthood. They begin with a "foundation year" in which students explore Rudolf Steiner's core ideas through reading, discussion, and artistic experience, then turn to more specialized training in subsequent years. Often, the foundation-year seminar includes all coworkers in their first year at Camphill, making it easy for those who initially made a single-year commitment to stay on for the entire seminar. Initially, the content of Camphill seminars was thoroughly anthroposophical; it functioned both to initiate participants into a personal identification with anthroposophy and to prepare them for the therapeutic tasks of Camphill life. Over the years, the approach has become more ideologically diverse, albeit to widely varying degrees.

Around the turn of the twenty-first century, several Camphills created structures to allow their young coworkers to receive formal academic credit for the experiential learning they do at Camphill. This idea was broached as early as 1976, but not realized at that time..$^{71}$ Recognizing that many young people cherish their time at Camphill but are unwilling to forego the benefits of university education (or to resist their parents' expectations for them), the designers of Camphill-based bachelor of arts degrees hope that these programs will make it easier for young coworkers to extend their initial year to four, and then perhaps to ongoing commitment as lifesharing coworkers. They also recognize that regulatory bodies often insist that caregivers hold vocational qualifications from accredited academic bodies. Of course, people with degrees in curative education or social therapy may have opportunities to take the skills they have learned at Camphill and obtain professional employment in other settings. But many Camphill leaders welcome this possibility. No one should stay at Camphill merely because they lack other options, and those who take their skills elsewhere are empowered to infuse some of Camphill's values into mainstream institutions.

Camphill School Aberdeen established its first BA program in the 1990s. Camphill Scotland hired multiple consultants to foster dialogue between longtime coworkers and external social workers, and the idea of a community-based curriculum was honed through this dialogue. ${ }^{72}$ The first educational partner was 
Northern College, a center for teacher training that was soon thereafter absorbed by Aberdeen University. The program then expanded to include other Camphill places in Scotland. From the beginning, it sought to bridge the best traditions of Camphill and the best insights of academia. Coworker Angelika Monteux, who helped craft the curriculum, explained the vision through an analogy with anthroposophical medicine. "Health is not in opposition to any illness," she observed, "but the active balance between two ills. . . So why don't we apply this simple insight to ourselves and our activities? If we want our contribution . . . to be wanted and really helpful in a world where everything is moving and changing ... then we need to enter dialogue, exchange, partnerships."73

Long-term coworkers served as the primary instructors in a self-contained program that was expected to meet the academic standards of a research university. This posed some challenges, explained Angelika Monteux in an interview. "We, and then the students, had to learn to explain anthroposophy and Karl König's ideas and Camphill to people who had no idea, in language that they could understand. It wasn't easy." Though some Camphillers could not adapt to the demand that they "teach, not just preach," and that they incorporate other educational theories besides those of anthroposophy, she found it invigorating. She was impressed by curriculum consultant Steven Baron, a former young coworker who had pursued an academic career as an educational theorist. The university trusted him because "he was a recognized academic"; the Camphillers trusted him "because we knew he was our friend." Nevertheless, "he gave us a hard time. I still remember that after reading our students' papers, he said, 'I get the impression that they say, Rudolf Steiner said, Karl König said, they don't discuss anything. That's not the students' fault. That's your fault, the way you teach as if everything is written in granite stone.' I will never forget that." ${ }^{44}$ Another teacher in the program, Marjan Sikkel, noted that the ideological pluralism of the BA renewed conversations about anthroposophy in Camphill. "When I came anthroposophy was a bit of a dirty word. . . . But then these young people started to ask questions about it. It came back in through the front door [after] it had come out through the back door. . . . But it was for them one of the different methods, not the main one and only." ${ }^{55}$ On the other hand, another teacher in the program observed that some of the university's expectations pushed students to a more abstract and less experiential understanding of anthroposophy. Confidentiality rules dictated that participants not write papers about specific individuals, and this deprived them of the chance to integrate the ideas they were learning with their therapeutic practice and thus make them fully their own. This, in turn, distorted their relationship with anthroposophy itself, which is meant to be experienced in practice and not merely known abstractly. ${ }^{76}$

Though Camphill had a positive experience with Aberdeen University, the university ultimately decided to terminate the program, with the final cohort of students completing their studies in 2014. As far as I have been able to determine, 
none of the people at Aberdeen University who had worked directly with Camphill were part of this decision. Camphill had a narrow base of support within the university; many people there were entirely unaware of the Camphill-based BA program. ${ }^{77}$ The program's vulnerability was exacerbated by a well-publicized controversy over an attempt to endow a chair of anthroposophical medicine at Aberdeen University. Because anthroposophical medicine includes homeopathy and herbal remedies that have not been validated by mainstream experimental methods, many people believe it should not be taught at universities, and these critics persuaded university officials to reject the chair and terminate the relationship with Camphill.

Almost immediately, Camphill established a new program with Robert Gordon University, a much younger school that announced its curriculum in "social pedagogy" in 2015. Based in the School of Applied Social Studies, this curriculum promised to "provide a holistic focus on the individual, family and community; explore emotional, psychological, physical, spiritual and sexual development across the lifespan; emphasise group care and community-based practice with a critical and reflective approach to application." ${ }^{78}$ This program is not as directly controlled by Camphill as the old BA: students complete courses (mostly online) taught by instructors employed by Robert Gordon, while their work in Camphill is treated as a form of field education. Their work supervisors in Camphill are responsible for evaluating the students' learning logs and other assignments, but Camphillers are not invited to craft the assignments themselves. Unlike the old program, the Robert Gordon program enrolls students affiliated with non-Camphill work sites, though Camphillers are the majority. This brings the benefit of exposing Camphill participants to other styles of social care, and giving them the opportunity to share the Camphill philosophy with outsiders. Another difference is that anthroposophy does not appear at all on the reading lists of Robert Gordon courses. This has challenged the host communities to be more conscious about how they "bring anthroposophy in" to the everyday work experiences of the students. Newton Dee, for example, offers a "further education course" to both second year BA students and other coworkers in their second year at the community." This is designed to provide access to anthroposophical ideas and Camphill traditions that relate to whatever topics are being covered in the Robert Gordon curriculum. ${ }^{79}$

The reviews of the new program are mixed. One work supervisor said that she appreciated being forced to read some of the same recent studies that are assigned to the students, and being forced to explain why she made certain choices as a house coordinator. She even found it helpful when students asked to try things that had failed in the past-because sometimes they didn't fail the next time. "Doing this kind of work you can also become stuck. And that is dangerous as well. I think new people coming in with fresh eyes who really want to do this work, can help this process in not getting stuck." ${ }^{\circ 0}$ But another person who has supervised students in both programs complained that the new is not nearly as rigorous as the 
old one. "It is not stressful," she said, "but it is not as interesting. It is not part of what people are doing with their daily lives. It is really a completely separate thing and it is also very easy. ... . We have some really good coworkers who are doing it and they are sticking at it . . not because they think it is exciting but because it gives them a paper at the end." Other participants, she said, had simply dropped out. By contrast, in the old program "they were stressed and they were complaining a lot and they had to reflect and they hated it, but they all came out really happy. They really felt that they had developed." When I asked her if Camphill had the power to improve the curriculum, she replied that yes, "we have the power to do anything," but "it is a priority thing." ${ }_{11}$

In the United States, Camphill has benefited from a diversified system of higher education that includes many alternative colleges committed to experiential learning. As a result, Camphill Academy-which began at Beaver Run in 2003 and now offers programs at most of the Camphill places in North America-has partnered with four different schools for its degree programs. Its two bachelor's degree programs, in curative education and in social therapy, follow a five-year format. During the foundation year and the three years that follow it, students take onsite courses taught by Camphillers while performing the usual coworker duties. They then transfer into a one year "BA completion program" offered by either Prescott College (an environmentally oriented alternative college in Arizona), SUNY Empire State (a public university), or Excelsior College (a private school in New York that specializes in offering distance learning to adult learners who are underrepresented in higher education). These schools offer distance learning courses to round out the curriculum, leaving students time to complete a Camphill-based internship. ${ }^{82}$ In addition to these programs, Camphill Academy partners with Antioch University New England to offer an MEd in Foundations of Education. Antioch University, a low-residency graduate school, offers several degrees and certificates related to Waldorf education. It is an offshoot of Antioch College, which has a long-standing connection to Camphill and other intentional communities.

In just a few years, Camphill Academy has transformed the culture of Beaver Run, and to some extent of the other Camphill places in the North America. Prior to its founding, one long-time coworker told me, the Beaver Run seminar had fallen on hard times: "It was a bit wishy-washy. . . . There was some basic anthroposophy in the first year, there was [Steiner's] curative education course in the fourth year, but there was not a complete overview, a wholeness. It was whatever we can offer. ... And to be honest there was one written paper, and that was the student's project in the end." ${ }^{3}$ The whole community sensed that rejuvenation was needed, and they found an inspiring leader in the person of Jan Göschel, a veteran Camphill teacher who was then pursuing a doctorate in special education from the University of Cologne. Göschel's first step was to redevelop the existing seminar program and have it evaluated for college credit equivalency, a process that is offered by the New York State Board of Regents. Through that process, they 
identified partner colleges with flexible degree-completion programs, and were able to get their first student through Prescott's program in 2008. They absorbed Camphill Copake's seminar, which provided the foundation for the social therapy curriculum. When they added other communities, they took on the name of Camphill Academy. Along the way, they articulated a multidimensional mission. "There is an aspect of the mission that has to do with bringing in and educating the next generation of people who are going to be able to take on leadership roles within the Camphill Movement and carry that into the future," explained Jan Göschel. "Another aspect of the mission is to create a model of adult learning, a prototype for adult learning that is embedded in community that integrates study, contemplative practice, artistic process ... an innovative higher education project in its own right, apart from its function that it has for the Camphill Movement." Finally, Jan said, the academy is "an offering of the Camphill Movement to the world that allows higher education within which an anthroposophical impulse lives." ${ }^{8}$

By 2014, the program enrolled forty students a year just at Beaver Run, shifting the emphasis within the young coworker community from "general one-year volunteers" to "people coming to actually study curative education." "Is that a mission change?" asked Guy Alma, who experienced the transition. "I don't think it is a mission change, but the professionalization and expansion of the numbers of people in that program and the programmatic depth of it, it is an intense, intense program." ${ }^{35}$ Camphill Academy has sent a great many of its graduates-probably the majority-into settings beyond Camphill. Both graduates of the BA and individuals who skipped the degree completion year have been able to get positions in special education in Germany, where the credentialing regulations are extremely detailed. Jan Göschel also mentioned a graduate who is helping to start a Waldorf school in Thailand, and he spoke with particular pride of a graduate who was able to get a position as a logistics coordinator for Doctors without Borders in South Sudan. The recruiter who hired him "was looking for somebody [able] to work in tight quarters with a very diverse group of people, to deal spontaneously with unexpected situations, to see a situation and come to an insight of what to do about it." And that was just what the academy's curriculum offered. ${ }^{86}$

Because Camphill Academy's academic partners play a minimal role in the students' first four years, the program is more deeply rooted in anthroposophy than either version of the Scottish BA. This creates a division of labor within the Camphill Movement, with English-speaking students free to choose either a deeply anthroposophical program in the United States or a pluralistic one in Scotland. As noted above, founding director Jan Göschel identifies the development of anthroposophical education as one-third of Camphill Academy's mission, comparable in status to its role relative to Camphill. Though not all students would identify as anthroposophists, those who are skeptical of anthroposophy would be unlikely to persist in the program, even if they loved Camphill. "People tend to 
have a sense," Göschel explained, "that this is something that they want to wrestle with and work with." ${ }^{\text {87 }}$

Anthroposophy, Jan went on, "was never envisioned as a static body of doctrine but actually as a practice and orientation" of inquiry and contemplation. "What we are trying to do," he elaborated, "is to build fundamental capacities, capacities of observation, capacities of inquiry, and an orientation that allows you to look at situations that don't fit into any roster whether it is a conventional roster or even an anthroposophical roster or whatever." Students and faculty alike strive to "strip away preconceptions" and "look at the essence of the phenomenon, and out of that come to insights into what actually is going on in that situation." That allows them "to move the situation further, to transform it, to bring healing or balance or whatever it is. . . That is the point of anthroposophy." He also suggested that the immersive, experiential character of Camphill Academy's program gives it an advantage over classroom-based trainings for anthroposophical initiatives. Topics like reincarnation or the role of Christ can be "hot topics" in anthroposophical trainings because "people come with all their baggage around that." But "because of the threshold experiences that people have through life and work here, things open up in a natural way." ${ }^{88}$ One practical implication of this is that Göschel, unlike the people running the BA programs in Scotland, has worked very hard to align his curriculum with the work of the School of Spiritual Science at the Goetheanum. Indeed, since 2017 he serves as one of three international leaders of the Anthroposophic Council for Inclusive Social Development, the international coordinating body for all anthroposophical initiatives related to persons with disabilities. ${ }^{89}$

Though Camphill Academy and the Robert Gordon program are the two BA options for Camphillers in the English-speaking world, there are similar programs available in both Germany and Norway. These have a somewhat different flavor, simply because Camphill constitutes a smaller share of the totality of anthroposophical activity (and of anthroposophical social therapy) in those countries than in the English-speaking world. Thus, Germany has an entire university, Alanus, rooted in anthroposophy, and the German Camphillers' BA program is offered through a Waldorf teacher training center that is under the auspices of Alanus. The Norwegian program, similarly, is sponsored by an anthroposophical school rather than a mainstream university..$^{90}$ The comparable institutions in the Englishspeaking world, such as Emerson College in England and Rudolf Steiner College in California, do not offer accredited degree programs that would satisfy social care authorities.

BA programs have increased the number of young coworkers who stay for four years instead of one, and this has transformed the participating Camphills. "You would have a stable coworker in your house, in your workplace," observed one leader at Newton Dee. "If every year you get a bunch of new people in, it takes quite a bit of time to train. Whereas if you have at least a couple of people staying, they can help train these new young people and it is not all falling on me. Also for the 
residents it gives some stability." ${ }^{11}$ BA programs have provided a path to long-term commitment for a small but significant minority. Especially at Newton Dee, the BA program had a snowball effect on the long-term retention of young coworkers. A few graduates, some of whom had started families together, chose to stay on indefinitely, and-as one person pointed out-that "attracts more young couples with small children." ${ }^{22}$ The experiential structure of the program, moreover, "kind of forced Newton Dee to give some younger people additional responsibilities and naturally work their way into the management structure," explained Jake Vollrath. "I don't think Newton Dee resisted. ... As I was doing the BA I needed to show that I could take responsibility for different kinds of things . . . and I just sort of built it up in a very natural organic way." ${ }^{93}$ Undoubtedly, these programs are a major reason why millennials are better represented than Gen Xers in the community of lifesharing coworkers, though it remains to be seen how many of those millennials will embrace Camphill as a lifelong commitment. BA programs have also driven something of a wedge between those communities that are large enough to host a significant cohort of students and those that are not: the latter are, perhaps, having an even more difficult time recruiting long-term coworkers than they would if the programs did not exist.

Even as BA programs make it easier for some young coworkers to stay for four years or even longer, most Camphillers agree that it is harder today than it was in the 1970 s to convert short-term volunteers into long-term coworkers. Many stress generational differences, while others acknowledge that many of today's young coworkers come earlier in life and for different reasons than their counterparts in the 1960 s and 1970s. It is not simply that millennials are less idealistic than baby boomers: one can find a great many highly idealistic millennials living at ecovillages or running organic farms, and some of these same people are also at Camphill. But today there is a well-worn path that also brings many less idealistic millennials to Camphill, said Jonny Mallam-Clarke. Many young coworkers are more interested in working with children with disabilities than they are in intentional community, but even the interest in the children is "secondary to something else, which is this idea that . . you should get as much experience from life as possible. If you can, you should travel and experience life in a different country.... Often the choice is not made by them as to whether they come to Camphill. It is part of a very set trajectory now that you go from school, you have a gap year, you go to university. The gap year helps you get a job, and the gap year also helps you get into university." One consequence is that even those who fall deeply in love with Camphill feel that they still haven't experienced life and are thus not in a position to make an informed commitment to Camphill. Their situation differs dramatically from that of Jonny himself, and of other coworkers who arrive later in their twenties. "If you are coming to an intentional community in your later twenties, in a way something has gone wrong. If you come to an intentional community when you are nineteen, it is how it is supposed to be." Perhaps 
not surprisingly, Jonny left Camphill and joined the Benedictine order soon after our conversation-a sign of his hunger for a more permanent alternative to the social mainstream. ${ }^{94}$

As Camphills seek strategies that will entice more young coworkers to embrace Camphill as a lifelong calling, they also accept that most will not make this choice. As early as 1975, Thomas Weihs articulated the intrinsic value of shortterm coworkers, both for Camphill and for the larger society. Like the graduates of Camphill schools, Weihs noted, the "young, sensitive, intelligent people with a strong social sense, who leave Camphill after a few years of experience, training and learning" have "a tremendous potential power to make a contribution to society." ${ }^{55}$ I have heard a similar message from many contemporary Camphillers. "One is always," explained one person, "amazed by young coworkers who come and have never experienced doing care work before and how they mature and grow and change during the year of that kind of experience." "Seeing the new faces of young people who are coming to join the community just for a single year," echoed Crispian Villeneuve, "is one of the best things still happening in Glencraig." ${ }_{97}$ Another person, Neil Henery, stressed that some of the gifts that young coworkers bring to Camphill are possible only because of the brevity of their stay. "There is a lot of strength and value in having young coworkers from all over, Germany and the Continent and Korea, coming for a year or longer and going. It really brings spark and life into the community." ${ }^{98}$

Yet another Camphiller, reflecting on the difficulties in recruiting long-term coworkers, mused that "at some point I stopped thinking, why do people not want to stay in Camphill anymore, and I started thinking, my mission now is to give people this experience for a year. I started to then see that the young adults with special needs were my coworkers and that the people we were serving were the young coworkers."99 This sentiment was endorsed by Veronika van Duin, who recalled that her husband had always said that "our work isn't with the villagers, our work is with the young coworkers who come. . . Give them that experience and then let them go out into the world." She added that it doesn't "matter terribly much whether Camphill ... is successful or whether it closes down. What matters is all the people who've passed through [our] doors and taken some of it out into the world. Seeds for social renewal." ${ }^{100}$ At Beaver Run, coworker Carsten Callesen gave a concrete example of this, recalling how a man he had known as a young coworker fifteen years before came back for a surprise visit. Now a manager at Airbus, he said that he could trace many of the techniques he uses to manage his staff "back to the experience he had of community living." Of course, Carsten added, "in order to make this possible we also need the people who come and stay."101

Because they see young coworkers as emissaries of the Camphill spirit to the world, Camphills are intentional about the experiences they offer to these young people. Much more than students, villagers, or employees, young coworkers are offered a thoughtful introduction to the writings and ideas of Rudolf Steiner, even 
though it is assumed that most will not embrace anthroposophy as their spiritual path. While employees are typically slotted into narrow functions, young coworkers are given a holistic experience of community life. They participate in as many different workshops as possible. They are expected to be present at most meals, to accompany villagers to religious services, to share their artistic talents, and to participate in community festivals. Camphill life would be greatly enriched if the movement were equally intentional about the formation of employees, parents, and board members.

\section{EMPLOYEES}

Almost everyone agrees that employees are the fastest-growing constituency within the Camphill Movement. If "employee" is defined capaciously to include everyone who receives a paycheck for work performed at a Camphill, they are probably already the largest constituency within the movement, outnumbering not only lifesharing coworkers but also students and villagers. For the purpose of this section, I will define employee more narrowly to include only nonresidential employees - that is, people who engage in neither lifesharing nor incomesharing. This group surely outnumbers lifesharing coworkers with a long-term commitment. To my knowledge, every Camphill place includes at least some employees in this sense, while a significant minority of Camphill places-among them, most of the communities that are part of the Camphill Village Trust in England and Wales-include no long-term lifesharing coworkers.

This is a new situation, dating only to the beginning of the present century. A movement-wide census conducted in 1976 identified just 218 paid workers out of 4,262 persons affiliated with Camphill (thus 5 percent of the whole), while a similar census conducted among the North American communities in 2018 counted 439 full- and part-time employees out of 1716 persons ( 26 percent), compared to 236 long-term lifesharing coworkers (14 percent), 237 short-term lifesharing coworkers (14 percent), and 425 residents with special needs (25 percent). ${ }^{102}$ Scotland's 2015 census identified 396 employees (28 percent), 171 long-term lifesharing coworkers (12 percent), 252 foundation students ( 18 percent), and 536 persons receiving support (37 percent). ${ }^{103} \mathrm{~A}$ year later, the ranks of the employees had swollen to 469 , while the other categories remained roughly the same. ${ }^{104}$ The shift is even more dramatic than these numbers suggest, for both in 1976 and in 2018 communities in North America and Scotland had smaller shares of employees than other Camphill regions, notably England, Wales, and Ireland.

The change is evident at each community. At Soltane, one leader said that "Soltane for the longest time had maybe 1, 2, 3, 4 employees and a whole big bunch of coworkers." Then they expanded "program activities," including off-campus activities for their students, and suddenly "we are headed towards about 30 employees, and about thirty to forty coworkers," including young coworkers. "So 
it is getting close to parity." ${ }^{105}$ During my visit in 2013, Grangebeg had ten villagers, four lifesharing coworkers, five or six young coworkers, and four employees. ${ }^{106}$ Solborg in 2016 reported about ten employees, some of them part-time, alongside twenty villagers, thirteen lifesharing coworkers, eleven young coworkers, and eight staff kids. ${ }^{107}$ I mention these numbers because they represent the Camphill median: more dependent on employees than the large villages that have vested all decision-making power in lifesharing coworkers (such as Newton Dee, Loch Arthur, and Kimberton Hills), but less dependent on employees than the schools and elder communities that require highly specialized staff.

The sudden presence of so many employees within Camphill constitutes an existential crisis: Can Camphill truly understand itself as an intentional community if most of the people who inhabit Camphill places during the day do not actually live there? Can Camphill claim to be an alternative to the institutions that once housed persons with intellectual disabilities if the people providing care and support do so for the sake of a paycheck? And can Camphill claim to be a community rooted in the ideals of anthroposophy if it violates Steiner's admonition that work be separated from income? Some lifesharing coworkers answer "no" to all of these questions. They insist that places without incomesharing and lifesharing are not authentically Camphill, and that places with growing numbers of employees are at risk of ceasing to be Camphill. Even Camphillers who have participated in significant ways in the shift toward employment express tempered worries. At Newton Dee, a coworker who supervises many employees told me that "because I am in charge of employment at Newton Dee, I am also very anti-employment." She explained that although "I am very keen that we have best practices and ensure people's rights are respected," she is also "keen to keep [employment] low where possible." Even though she knows many people who say their work is not affected by the fact that they do it for money, she is skeptical. "It is easy to underestimate the power of what money, a direct salary, does to an attitude and an atmosphere. I think there are a whole lot of things that are not obvious now, but that would slowly destroy what we have."108

Other Camphillers reply that the employee group is the evolutionary cutting edge of the movement. Employees stand at the creative boundary between the intentional community and the larger society, poised to infuse communal values into the neighborhoods that surround each Camphill place. Yet this will happen only if the Camphill Movement finds ways to structure employment in alignment with communal and anthroposophical values, rather than treating it as an unfortunate concession to necessity or outside demands.

Several factors have contributed to the increasing numbers of employees in Camphill. Almost from the beginning, most Camphill places employed a few people to perform tasks that were peripheral to the core mission of Camphill and of little interest to lifesharing coworkers. This was the pattern at Camphill Village Minnesota when I first spent time there at the turn of the new millennium. In 1999 
there was, to my knowledge, one employed person in the village: an office manager who answered the phone, managed paperwork, and assisted the lifesharing coworker who was designated as the community's administrator. She was wellknown to everyone in the community, since she joined coworkers and villagers for lunch in village houses every day. But her life rhythms marked her as separate from the Camphillers. She worked nine to five and did not take a full hour of "rest period" after lunch. She was more truly "at home" in the nearby town where she lived with her family. Within a few years, the employee group increased to three, as the village hired a fundraiser and a staffperson responsible for recruiting young coworkers, both part-time. (For a time, my spouse played the latter role.) Like the office manager, these employees were well-known to the Camphillers, but not perceived as members of the community.

The numbers of employees performing office work has increased as the structure of Camphill has become more bureaucratic, in response to pressures from the larger society. When Camphill began, governments took little interest in the care of persons with intellectual disabilities and thus made few demands on the places offering care. Now, most governments mandate inspections, formal policies, and record keeping on issues ranging from meal preparation to safeguards against sexual abuse, and individualized plans for each person receiving care. They also demand formal credentialing from some of the people performing care tasks, especially educational and nursing tasks. Teachers at Beaver Run, for example, may have as many as three formal credentials: as state licensed special educators, as anthroposophical curative educators, and as Waldorf teachers. ${ }^{109}$ Many coworkers came to Camphill because they preferred face-to-face relationships over bureaucratic structures, and some of these coworkers are unwilling or unable to produce the sorts of reports and records required by inspectors. At the same time, most Camphill places have discovered that they can greatly increase their income by employing fundraising professionals. Guy Alma, who runs the development office at Beaver Run, told me that in about a decade he had expanded the office from one part-time person to three full-time employees in addition to himself-with a positive impact on the community's bottom line. ${ }^{110}$ And the immigration laws governing international coworkers have become increasingly complex, necessitating another set of specialized tasks that are of little intrinsic interest to the typical coworker.

The increase in the number of Camphill employees has also been driven by the decline in the number of long-term, lifesharing coworkers. The influx of baby boomer coworkers in the 1970 s and early 1980 os led to a great increase in the number of Camphill places, and when that influx slowed, many of those places found themselves short of teachers, workshop leaders, and residential caregivers. In 1982, an advertisement seeking new coworkers in the movement's newsletter provoked a surprised letter by a Camphiller who said he "would never have dreamt of the day where we would see our work depend on this mode of recruitment," but within 
five years "Coworker Needs" was a standard feature in virtually every issue. ${ }^{111}$ By 2000, the newsletter carried alarming articles that proclaimed that "wonderful, lively and thriving" Camphill places were "in a crisis and might have to be dissolved!" because of the difficulty in finding long-term coworkers. ${ }^{112}$

The loss of coworkers has forced most Camphill places to employ people to perform tasks that are also performed by lifesharing coworkers, and that are central to Camphill identity. This trend is most pronounced in Camphill schools and elder communities, because of credentialing demands. Adult villages, town communities, and training colleges have generally preserved a higher ratio of coworkers to employees, but most of these have still found it necessary to employ some workshop leaders. In some cases, villages have found that employed workshop leaders remain in their positions longer than lifesharing coworkers (even those who initially came with an open-ended commitment), and thus rely on employees to maintain stability and "relieve the coworkers of a lot of pressure." ${ }_{113}$ Villages are often more willing to accept employed persons as workshop leaders than as house coordinators, since the latter would undermine the core value of lifesharing. At many Camphills the degree of existential anxiety about employment is directly tied to the question of whether they've had to start employing house coordinators. When I visited Newton Dee in 2013, for example, they had recently appointed temporary coordinators of two of their houses in the hope that they could avoid resorting to employees. ${ }^{114}$ When I returned in 2016, the fact that they had maintained their commitment to lifesharing house coordinators was repeatedly cited as evidence of the overall health of the community, even though almost all of their workshop leaders were employees. Similarly, leaders at Beaver Run took great pride in the fact that "we have no employed staff in the houses," even as half of their teachers were employees. ${ }^{115}$

The increase in bureaucratic tasks and the decline in long-term coworkers has brought about a situation in which employees and coworkers work side by side in many Camphill places, with the ratio between the two shifting toward the employees. Other Camphills, however, have rejected either incomesharing or lifesharing altogether, making employment the standard model for all persons performing educational or care tasks. (Or, in some cases, they have made employment the standard practice for all long-term caregivers, but have retained short-term volunteers.) Usually, this has occurred in response to pressure from social care authorities or other government bodies, and it has taken place in roughly two waves. The first wave began as early as the 1970s, when Cresset House in South Africa began employing teachers with government-approved qualifications in anticipation of new regulations. ${ }^{116}$ It intensified in the 1980s, when several European governments rejected the practice of incomesharing as a violation of labor laws. These governments required that anyone performing a care task receive a just wage for their work; in some cases, they also mandated that different wages be paid to workers performing tasks of different levels of complexity. This posed a challenge to 
Camphill's egalitarian ideals, but it did not disrupt other aspects of Camphill life: employees could still be given housing as part of their employment package, maintaining the tradition of lifesharing. In many cases, coworkers who were forced to accept employment status set up voluntary incomesharing pools.

The European model of employment has proven attractive enough that some Camphills have adopted it even though they are not required to do so by their governments. In principle, Camphill incomesharing separates work from income, allowing each person to contribute their best gifts freely to the community, knowing that their basic needs will be fully met. In practice, it can create awkward injustices, if some people are comfortable asking for nice clothes and exotic vacations and others are not. It can also be time-consuming and emotionally draining for people to describe all of their economic needs and desires to their fellow workers. It is simpler, some Camphills have concluded, to give everyone a roughly equal salary, coupled with the provision of free housing, and to maintain a "social fund" to which people may apply for additional funds in case of emergency. Other Camphills believe that the practice of collectively distinguishing "wants" from "needs," though awkward, fosters spiritual growth and communal cohesion. Some of these places have preserved the practice of asking coworker individuals and families to request funding based on their unique needs, but then convert these requests into conventional salaries. This allows them to make the commensurate payments into government pension funds (such as Social Security in the United States), ensuring a level of financial security should those coworkers spend their retirement outside of Camphill. People who are compensated in this way generally regard themselves as incomesharing coworkers, not as employees. But there are nearly as many variations on this theme as there are Camphill places. In some, the distinction between coworkers and employees has virtually disappeared, as residential and nonresidential caregivers are compensated in the same way. In others, there is a bright line separating the groups, with certain leadership roles available only to those in the coworker category. Similarly, some employmentbased Camphills have salary structures that mirror those of mainstream social care, while others offer salaries that are either all equal or only slightly differentiated. One Camphill place, for example, told me that the ratio between their highest and lowest salaries was seven to six.

As employment has become more visible within Camphill, some lifesharing coworkers have chosen to become employees. The reasons for this are diverse, though finances per se are rarely the deciding factor. The graduates of BA programs, for whom their years as young coworkers were in effect their college experience, sometimes tell their communities, "I've finished my training and now I'd like to move out, but I'd be happy to be employed to come back and run the house or run the workshop." The community often agrees, one person told me, not with "great positivity" but because "we see that as the way it is going to go because that is what people want." ${ }^{117}$ Former staff kids, similarly, often have the skills needed to 
make a valuable contribution to Camphill but prefer to raise their own families in less intensely communal circumstances than what they experienced in their own childhood. Russ Pooler, for example, described his son's life as a paid manager at a Camphill school. "He grew up in Camphill so he loves the villagers and loves the life, but anthroposophy means almost nothing to him." When he began his job, the community was paralyzed by the opposition of a group of "old hardened anthroposophists" who wouldn't allow anything to change. "He managed to persuade them to leave. This wasn't the place for them. And now it has changed. It is a wonderful place now. It is thriving. People are happy. There are some committed coworkers there. That to me is the kind of freedom that you get in anthroposophy." ${ }^{118}$ In Norway, I met a community manager who moved out of Camphill in order to create a more stable home for his own special needs child, and in the United States I heard a similar story from a manager who said that she "lived in homesharing, lifesharing for twenty-seven years, and now I don't do homesharing anymore. I live with my son, separately, on campus. I am really grateful that that is a possibility." ${ }^{119}$ Another person observed that sometimes it simply boils down to the different preferences among individuals: "When I was a little kid, my mother asked my sister and myself, I can either give you a dollar a week, or you can just ask for whatever you need when you need it, and maybe you'll get it and maybe you won't. My sister said I want my dollar. I said I want to just ask when I need something. And both of us think we had the better deal." "120

A final factor has increased the number of Camphill employees in a numerically small but highly significant way. Several Camphill places have experienced crises-variously involving financial mismanagement, failure to comply with government regulation, abuse of students, villagers, or staff kids, or conflict among coworkers-that have provoked their governing boards to hire outside managers capable of bringing them back in line. On the face of it, this is an odd choice, since the same sorts of crises frequently occur in places with conventionally hierarchical management structures. I know of at least one Camphill place that brought in an employed manager in response to a crisis, and has experienced a similar crisis under the employed manager's watch. Yet it is understandable that boards often have a bias toward more conventional governance structures, since many board members are not deeply grounded in either the lived experience of intentional community or anthroposophical ideals. Both the laws governing the fiduciary responsibilities of board members and the government agencies that provide funding for Camphill places presuppose an administrative structure in which a single executive director is answerable to the board, and in times of crisis many Camphill boards opt for that model. There have also been cases when, even in the absence of a crisis, local authorities have demanded that Camphills appoint a single contact person for the sake of their inspections, and Camphill boards have complied by naming a manager. ${ }^{121}$ And so the "employed manager" has joined office workers, teachers, workshop leaders, and house coordinators in the roster of Camphill employee types. 
Some, though certainly not all, of these employed managers harbor deep reservations about the practices of incomesharing and lifesharing. In tandem with the boards that hired them, these managers have implemented employee-only models in many Camphill places outside of continental Europe. In some cases, they have limited or eliminated the practice of lifesharing as well-sometimes asking all coworkers to live offsite, sometimes refusing to accept residential coworkers with families, sometimes providing in-community housing to young coworkers but not to those who make a longer-term commitment.

In other cases, employed managers function as translators between the culture of Camphill and that of social care authorities. At one Camphill place in Ireland, I met a woman who had been brought in by the local authority to monitor the community's compliance with regulations, in the wake of a crisis. Technically, she was not a Camphill employee but a government employee, yet her role was similar to that of employed managers in other places and she had facilitated the process in which the community brought in its first employed manager. Since her government employers openly referred to her as their "eyes and ears", it was not surprising that she met some distrust on the part of the Camphill coworkers. "I was seen as the face of regulation coming in and the slippery slope of the end of life as they knew it." Still, she was able to make practical changes without disrupting the entire ethos of the community. In the past, she said, a problem would come to one group and that group "would say we have to take it to this group or that group, and somewhere in the midst of that it gets lost or it gets dated and then nothing ever happens." Her response was not to replace the groups with individuals, but simply to create a single "social care coordination group that would take responsibility for all the social care issues within the community." "They are struggling," she summed up, "to find a way to change while still maintaining an ethos and a culture and a value base." ${ }^{122}$

Given the diverse paths by which Camphill places have accepted the practice of employment, it is difficult to generalize about the experience of Camphill employees-more difficult, in fact, than it is to generalize about students, villagers, young coworkers, or lifesharing coworkers. All of those groups have social roles that are embedded in Camphill tradition, and understood in roughly similar ways from one Camphill place to the next. The one thing employees have in common, by contrast, is a significant dose of role ambiguity. Their presence at Camphill is widely regarded as a concession to necessity rather than an expression of idealism, and for the most part they are neither asked to uphold Camphill's communal and anthroposophical ideals, nor given the tools they would need to uphold those ideals in a meaningful way. Many have not been provided a formal orientation to Camphill traditions of the sort that is routinely provided to members of the other constituencies; others have participated in coworker orientations at their individual request. Some communities do routinely include new employees in their orientation practices, but these employees cannot assume (as coworkers 
most certainly can) that the Camphill employees they meet from other places will have been similarly oriented. Thus, when I ask Camphill employees whether they see themselves as among the people responsible for carrying Camphill into the future, they almost always struggle to form a reply, because they do not know whether the movement has truly invited them to play such a role. Many lifesharing coworkers also struggle to reply, but for a different reason: they know they are invited but are not sure whether they wish to accept the invitation.

This is unfortunate, because employees have enormous gifts to offer the Camphill Movement. Even critics of the trend toward more employment readily recognize that "some of our employed people are the best people." ${ }^{123}$ But employees" gifts, at the present time (2020), are exercised almost entirely within the narrow ambit of the specific task for which the employees have been hired.

Employees contribute, first and foremost, an enthusiasm for Camphill's holistic, communal ideals that they share with coworkers, students, and villages. Very few work for Camphill out of sheer economic necessity; most have embraced Camphill at least in part because it offers an alternative to the values of mainstream society. As one Camphiller pointed out to me, the choice to participate in care for persons with disabilities is itself a countercultural one that is not highly valued in the mainstream: "My experience is that if you do care work you don't work for money anyway. This is not the most highly paid profession." She also noticed a deeper level of commitment among the employees with whom she worked at Simeon Care for the Elderly. When she interviewed them as part of a conference presentation, "what came across very strongly was their own wish to create a kind of homely atmosphere in Simeon, to continue that sense of home even though it's not their own home." Significantly, many felt that this atmosphere would not be present without at least a few lifesharing coworkers. For these employees, in other words, being part of a social organism that included both lifesharers and employees was a core value. ${ }^{124}$ At Newton Dee, Russ Pooler reported that when their community offered a yearlong "ethos of Camphill" workshop for their employees, they were surprised to discover that "what they were most interested in was anthroposophy. . . . It is totally fascinating if you can actually see it happening as you can in Camphill. ... People are really interested in exploring. You gain an awful lot of good will." ${ }^{125}$

I also felt a strong sense of affinity with Camphill's lifesharing values from Fran Pioli, an employee whom I met at Cherry Orchards. She fell in love with the community during a practicum for a degree in occupational therapy, and when she graduated she persuaded Cherry Orchards that they needed a permanent therapist. She thought about becoming a lifesharing coworker, but because she had already been living locally for many years, she felt that "the strain of living so close to my old life without being able to access it in the same way ... would probably make me resentful." This is a challenge that doesn't arise for coworkers who leave their previous communities (and often, their home countries) when they come to Camphill. Fortunately for her, the coworker community at Cherry Orchards affirmed the 
particularity of her situation and accepted her as "an employee, a coworker, and currently part of the management group with a view to becoming one of the registered managers." She participates in all aspects of decision making except the allocation of trust money, and even there she doesn't feel excluded. Because she doesn't experience her role at Cherry Orchards as simply a job, she often participates in festivals that take place outside of her work hours-though she also feels free not to participate if she has a schedule conflict or isn't moved by a particular festival. She also said that the other employed coworker at Cherry Orchards, who had previously been a lifesharing coworker, related to the community in a manner similar to hers. Cherry Orchards also had employed gardeners with a more distant relationship, though one of them had recently begun participating in a weekly group designed "to teach coworkers about the basics of anthroposophy." ${ }^{126}$

Many employees, especially those who serve as workshop coordinators, bring an inspiring level of devotion to a particular craft or vocation. At Newton Dee, I was consistently impressed by the level of expertise and commitment expressed by the leaders of the garden, the bakery, the joinery, the toy workshop, and the craft workshop. These employees spent all or most of their time in a single work space, were in active conversation with practitioners of their craft beyond Camphill, and had thought deeply about how to cultivate an ethos of excellence among the adults with special needs who worked in their workshop. It is easier for a villager to think of herself as a baker or a gardener, rather than a recipient of services, if she is taking direction from someone who also sees herself as a baker or a gardener. To be sure, lifesharing coworkers could bring the same level of focused devotion to a craft, if the community asked them to do so. Many Camphill farmers are exempted from certain household responsibilities in order to make this possible. But the majority of lifesharing coworkers, historically, have been people who thrive on a diversity of tasks, and as the number of coworkers has declined, they have been stretched thin between household and bureaucratic responsibilities. In this context, the professionalism of workshop leaders creates a balance in the community that mirrors that of the larger society, reducing the risk that Camphills come to resemble the old institutions.

Employees can also deepen a Camphill's connection to the anthroposophical movement as a whole-though I have seen this only in a few places, and in most cases it is not even imagined as a possibility. In places where Camphill is a relatively small part of a vibrant local anthroposophical scene, employees may function as bridges to other initiatives. Many people employed at Cascadia in Vancouver, for example, had previous connections to the large local Waldorf school, and the same thing often happens in German Camphills. Conversely, in Camphill places that are isolated from other anthroposophical initiatives and that have few or no lifesharing coworkers, employees sometimes take the personal initiative to renew spiritual practices inspired by Steiner. In one such place, I met a carpentry workshop leader with no previous connection to anthroposophy, who had been 
inspired, simply by virtue of his community's past history, to educate himself in Steiner's thought. When I visited, he opened his workshop with verses from Steiner, offered with the enthusiasm of fresh discovery rather than the habit of long-standing tradition.

Employees also help the Camphill Movement think about how anthroposophical values might be instilled in society as a whole, and not simply in incomesharing communities. The anthroposophical ideal that work should be distinct from income can be (and has been) expressed in diverse institutional forms, as can the ideal that the economic sphere be governed by "brotherly" sharing. During the period when all Camphills had adopted the same forms, Camphillers didn't do much thinking about this; now, when they have a plethora of forms from which to choose, the conversation is active and energetic. "How does the Fundamental Social Law manifest itself?” asked Mischa Fekete at the Bridge Community in Ireland.

Does it mean that because they are paid they are not living out of the Fundamental Social Law, or does it mean that the key question is, do they work because they are paid or do they work because they want to contribute to this unique impulse and be a part of that and out of freedom give in that way and the payment is in a way a way of meeting their needs. And I think both happen. You can have employees that, really it is very clear, my hours are up and I am gone, and you have employees that come to every festival and every birthday celebration and everything else. And the key question is how can the community also communicate its vision, communicate what we are trying to do, make those events so exciting that of course people would want to be there? ? $^{127}$

Long-term coworkers who have moved from traditional to employment-based Camphills are thoughtful about this. One such person told me that the traditional system had never felt "equitable" to her as a single person, and that "there was a tremendous amount of time and energy put into what I felt were petty concerns." At the same time, she admitted, her conscience still prodded her to do more to promote "brotherliness in the economic sphere." Another person from the same community observed that in incomesharing communities the system could be "just weighted toward physical development, we need more cars, we need more house, we need more tractors, we need a better barn." But she also hoped for more conversations on economic sharing, especially as the needs of aging coworkers and villagers became more diverse and complicated. Yet another person in that community observed that they were just beginning to think about how best to provide financial support for retired employees and keep them appropriately engaged in the life of the community. Still another said that when she first arrived she "felt so rich," simply to have a small paycheck that allowed her to give money to a beggar. Later, she joined a study group on the threefold social order, and was thrilled to be in conversation with other people with different opinions, all striving to overcome their biases and judgments as they discern how to use money as a tool for greater connectedness. ${ }^{128}$ 
At another Camphill place that has moved significantly toward the employment model, two leaders told a complex story of how their community makes changes without abandoning Camphill's values - all the while insisting that the entire debate about employment is less significant than the conversation about how to more fully empower persons with learning difficulties. "To me it is immaterial whether somebody draws a salary or not," one said. The important thing is that no one feels like a second class citizen. ${ }^{129}$ Her colleague Adrian Bowden added that "we are trying now to make it clear that everybody who works here has some kind of role description, which includes an element of a review process around that role." Another priority is to create more flexibility within lifesharing, creating semi-autonomous living spaces when this will allow both coworkers and villagers to make personal choices about such things as vegetarian diets. Drawing on his previous experience in Norway, he mused that one long-term solution might be to "create a separate coworker organizational body" that would negotiate an overall staffing contract with Camphill based on standard salaries for specific professional roles, then distribute the payment according to its own incomesharing ideals. This would free the Camphill to interact with the social care authorities on their own terms, and the coworkers to "work through their stuff" on a more spiritual basis. ${ }^{130}$ Over the following years, these musings prodded the community to reorganize itself along the lines of Steiner's social threefolding. The senior coworkers organized themselves into a local "association" intended to serve as a "rights sphere organ where everyone in the community had an equal voice," while separate bodies operated in the economic and cultural spheres. ${ }^{131}$

Even in the places where conflict over employment is most intense, many Camphillers recognize that the situation is an opportunity for spiritual growth. In the midst of the conflict between the coworker community at Botton Village and the leadership of the Camphill Village Trust, coworker Ruairidh von Stein mused that "employees are no different than we are, because it doesn't make any difference whether you have money or not money. . . . There are karmic threads that pull everybody out into this particular spot. . . . If you spiritually start pulling the threads, whoever it is that is pulling these people together to serve a purpose, there must be a reason for that. . . . We are all in the same boat . . . and that boat can be about creating good neighbors, good relationships." ${ }^{132}$

Some of the Camphillers who are most deeply rooted in anthroposophy insist that the real threat to Camphill's spiritual integrity is not the fact that some people are employed but the sharp distinction between coworkers and employees. "The whole ethos of working out of loving and working because you want to do it is not impaired or endangered by the fact that you are paid for it," insisted one Camphiller (herself an incomesharer). ${ }^{133}$ Veronika van Duin made the point even more energetically: it is "a huge moral challenge," she said, "to practice the threefold social order in today's Camphill communities." In order to meet the challenge, one must "become a real anthroposophist," and the "first step" toward that end "would 
have to be that Camphill would stop separating waged, salaried people from volunteer coworkers, and would look at everyone as members of the Camphill community who work for the good of the development of the community, and it doesn't matter where they get their money from. It is irrelevant." Her abrupt turn from "real anthroposophy" to abolishing the employee/coworker distinction startled me, and at first I thought she might mean that Camphill needed to stop having paid employees. But her point was just the opposite. Her wish was for everyone in Camphill to start practicing the core disciplines of anthroposophy, which include overcoming biases and preconceptions and being open to new experiences and perceptions. Specifically, it "would involve those who are salaried wanting to take up the study of anthroposophy" and "volunteer coworkers [not thinking] they are better because they don't take wages, without recognizing how much in real cash terms they get." "Both are at fault," she said, then caught herself: "It is stupid to call it fault, but both need to take a step towards each other for community to survive." Ultimately, Veronika added, it might also require Camphills to "separate ourselves financially from the state so that they would have no tune to call," making it possible for Camphill to evolve a genuinely threefold social order. ${ }^{134}$

The sharpest critique I have ever heard of traditional Camphill lifesharing came not from an employed manager with no connection to anthroposophy, but from a passionately committed anthroposophist who began as a young coworker and then made an active choice to be an employee rather than a lifesharer. "I am going to be very honest," he told me. "Some people in relation to Camphill are milking the cow a lot. ... Everything organic, good cars, good clothes. A very expensive life. ... They are complaining all the time because they are working and living with people with disabilities, but they don't realize they have between five and ten [young coworkers] cooking, cleaning, and working with the [villagers], twentyfour hours, and their life is just to be there. . . . We want to provide the [villagers] a family experience. Is that a family experience? . . . I have my family, and when I go to my home there is not another three guys cleaning, cooking, and doing everything for me." He and his partner have twice refused to be houseparents because they believe that "life needs more fight. . . . If you really want to grow, you need to pass through some struggle. ... We need to cooperate with the world. And the only way we can cooperate with the world is to experience the world. That is why I think it is important to have employees." ${ }^{135}$

Though not all Camphillers would endorse the fullness of that critique, most recognize that employees have a precious capacity to mediate between the community and the world. They are the ones who move, quite literally, between the two places on a daily basis. One Camphiller described employees as a "bridging ring" around the community, noting that the parents of students and villagers often played this role before there were large numbers of employees. ${ }^{136}$

At the Bridge Community in Ireland, Mischa Fekete told me that the presence of employees has given the community a fluid and permeable boundary that 
expands or shrinks depending on the circumstances. "When you go to an inner esoteric celebration of a festival, suddenly the community shrinks to become a very small nucleus, and in a different moment suddenly the community experiences itself as being way bigger than its physical boundaries and including way more people." Though some people find that oscillation to be challenging, others "see it as the future, and part of the future mission of our communities to become impulse-bearers in the world rather than insular communities." ${ }^{137}$

One reason employees are able to play a bridge-building role is that most of them are natives of the place in which the Camphill is located. It is common, on the other hand, for a majority of lifesharing coworkers to come from other countries. When I visited Camphill places in Scotland, for example, I joked that I never had to contend with Scottish accents because I was always speaking to Germans with flawless English. (When Camphill Scotland assessed the potential impact of Brexit, they discovered that only 39 percent of long-term coworkers and 2 percent of short-term coworkers were UK citizens, compared to 67 percent of employees.) My ear for accents was challenged much more when I visited Blair Drummond, a training college that abandoned lifesharing (except for young coworkers) in a crisis a decade earlier. The employed managers who facilitated my tour were proud natives not merely of Scotland but of the Stirling district. For them, the strengths of their community and the strengths of the city in which it was located were a package deal, and this translated into an obvious capacity to help Blair Drummond's students fully access the resources of the city. It was equally clear that they had a long-term commitment to Blair Drummond itself, in contrast to many devoted Camphillers who, precisely because of their devotion to the Camphill Movement as a whole, willingly move from one Camphill place to another in response to those communities' needs. My observations at Blair Drummond were confirmed when I visited Garvald-an offshoot of Camphill founded by several of the founders who chafed under Karl König's authoritarianism-and met someone who started working there in 1981. In that year, he recalled, "I was the only Scottish person there," while most other coworkers were from Germany and Switzerland. Today, Garvald consists of a rural community with residential and day workshops, a smaller biodynamic farm community, and an energetic urban network of day workshops for people with special needs, staffed entirely by British people. ${ }^{138}$

Other employees play a bridge-building role because they also come from far away, but for reasons quite different from those of traditional coworkers. I observed this at Camphill Vidaråsen, located a couple hours' train ride from Oslo, which is the oldest and largest Camphill place in Norway. Like all the Camphill places in Norway, Vidaråsen has preserved a traditional system of lifesharing, but classifies all of its nondisabled residents as "employees" who earn wages in addition to receiving room and board.

Vidaråsen's embrace of the "employment" model had an unanticipated consequence: a large share of its employees, especially those with the nursing training 
required to do lifesharing with elderly persons with disabilities, are immigrants from the Philippines and Nepal. Unlike the Western volunteers who populate most other Camphills, these immigrants did not come primarily seeking community; they just hoped to earn enough to send a remittance to family back home. Vidaråsen's hybrid economic structure, in which many employees live in lifesharing households where their basic living expenses are all covered, makes it easy for them to send most of their paychecks home. These immigrants adjust easily to community life, since they grew up in tightly integrated traditional rural villages. The Norwegians and other Westerners at Vidaråsen have, in turn, embraced the distinctive gifts of their immigrant companions. At the time of my visit, for example, all the energy in the community was focused on the construction of a simple home that was intended as a pilot for a service project in Nepal. Several of the Nepali Camphillers were from a village that had been impacted by an earthquake, and Vidaråsen's plan was to build a home alongside local people, who would gain new skills for building similar homes throughout their community.

Employees, in short, are already a vital part of the Camphill organism, making significant contributions both as individuals and as a group. But at most Camphills, the potential contributions of employees are limited because the employee role is understood in functional rather than holistic terms. Employees are hired to perform a specific function, and rarely invited to form a holistic connection to the entire community. This begins with the hiring process. "We employ people to do what we are not able to do," said Diedra Heitzman of Kimberton Hills, and this is a practice that made sense when "what we are not able to do" consisted primarily of specialized tasks that were peripheral to community life. ${ }^{139}$ But the same attitude has persisted as "what we are not able to do" has expanded. Veronika van Duin summed it up more caustically, observing that Camphills don't "say to people who come, are you interested in community, are you willing to do anthroposophical training, because this is what we practice and you've got to learn what we practice. They don't. They just employ people who seem to be nice people with the right qualifications." ${ }^{140}$

One Camphiller, Mischa Fekete, told me that an administrator at his community referred to anthroposophical spirituality as "the fluffy stuff," and generally said that "I love it and it is great, but I don't know and I don't need to know." 141 In my experience, this is the attitude of the substantial majority of Camphill employees. What is more, it is the attitude that Camphill coworkers expect their employees to have. When employees constituted a small share of people affiliated with Camphill, it made sense to select people with a distant and indifferent attitude toward anthroposophy, since many communities were suffering from too much insularity and needed the perspectives offered by persons immersed in mainstream society. But few Camphills have shifted their hiring priorities as the balance between employees and coworkers has shifted. And those that have report that change can be challenging: "The trick is finding the people who are interested in living as community 
members regardless of money," explained Jake Vollrath at Newton Dee. "It is easier to find those people when we go for the unpaid model. . . . As soon as you start paying people you get all the other applicants ... and you are looking for a needle in a haystack." 142

The tendency to select employees based on their qualification for a particular task rather than their holistic commitment to the ideals of Camphills can have particularly damaging consequences when the employee in question is a manager. Again and again, I have heard coworkers make blistering complaints about employed managers who are hostile to lifesharing or anthroposophy, as well as more tempered criticisms of managers who want to do the right thing but are hampered by the fact that they "kind of get it on an intellectual level" but don't have an experiential grounding in Camphill's ideals. ${ }^{143}$ I often ask: why doesn't Camphill simply make familiarity with anthroposophical lifesharing a job requirement when it hires employed managers? After all, there are many anthroposophical initiatives, such as Waldorf schools and clinics, where people can gain some of the administrative skills that may be lacking among the coworkers of a particular Camphill place. Many Camphillers struggle to answer this question; others point out that the decision is typically made by boards rather than coworker communities, and the boards themselves have been selected without reference to their commitment to Camphill ideals. My own sense is that managers are often hired at a time when the community's most pressing problem is its lack of facility with the culture of the social care authorities, and so familiarity with that culture becomes the number one qualification. This creates a built-in conflict: the community sees the manager's role as primarily one of mediation with the larger society, while the manager assumes that her role is to oversee all aspects of organizational life.

After being selected in a functional rather than a holistic way, most Camphill employees receive an orientation that is equally functional. To be fair, this is not universally the case and it is changing. Camphiller Mischa Fekete, when asked about this, said "it is something that we are waking up to." But it is still the exception rather than the rule for employees to be offered the sort of comprehensive introduction to Camphill life that is a standard part of the young coworker experience. Indeed, Mischa went on to express worries about the legality of imposing anthroposophy on employees: "I don't think you can make employment of someone conditional on them being anthroposophists." ${ }^{144}$ Similarly, Carsten Callesen said that "we try to leave people free and also wait for them to pose the question," alluding to Rudolf Steiner's teaching that it is an imposition on someone's spiritual freedom to answer a question they have not yet asked. ${ }^{145}$ In some places, employees are free to choose whether or not to participate in the foundation year experience alongside the young coworkers; in some places, they must do so on their own time rather than as part of their paid responsibilities. Since employees typically have radically different life circumstances than young coworkers (for example, they are older, usually have family responsibilities, and are living in their home 
countries surrounding by networks of family and friends), orientation programs designed primarily for young coworkers can be uncomfortable for them. At Glencraig, Tracey McCoubrey, an employee who had participated in that community's seminar, told me that without that experience she never would have been able to step into a new role as an employed house coordinator. "That's really given me skills and the obligation to do it." But she also acknowledged that of the four other employees who started the seminar with her, only one completed iteven though all continued in their roles as employees. ${ }^{146}$

The work responsibilities of most Camphill employees, moreover, are defined in the same functional way that they were hired and oriented. An employee may be hired to run the carpentry workshop, or direct the fundraising office, or staff the community café, and these responsibilities will not change unless they apply for a different job. A lifesharing coworker, by contrast, might cycle through all of these tasks in response to the community's needs, and typically will have two or more quite different "jobs" simultaneously.

In suggesting that the work responsibilities of Camphill employees might be defined more holistically, I am not contradicting my earlier argument that employed workshop leaders offer an important gift to Camphill by maintaining a focus on a single craft. A holistic job description need not mirror that of the typical coworker who spends a few hours a week cooking, a few hours providing therapies, a few hours going to meetings, and a few hours running a workshop. It would simply need to incorporate some of the activities that instill a sense of membership in the community: eating meals in the houses, attending festivals, representing the community at regional or international Camphill gatherings. Many Camphillers worry that it is unfair to ask such things of employees, but the unfairness applies only if they are not incorporated into the job description in a transparent way. Were that to happen, Camphills would doubtless attract employees with more intrinsic motivation for community life. But so long as the focus is on minimizing the total number of employees, it is difficult to embrace such strategies. Indeed, one longtime Camphill employee told me that as the number of employees in his community rises, the boundaries between them and the life of the community have risen. When he was first hired, it was assumed that he would eat his meals in the houses, but now that is allowed only on special occasions.

My sense is that many Camphillers assume that a functional rather than holistic identity is intrinsic to paid employment. After all, Camphill historically opted for incomesharing and lifesharing because the founders believed these practices were most conducive to the sort of holistic community that would be both therapeutic and empowering for persons with special support needs. That was a reasonable choice then, and it is still a reasonable choice for many Camphills to cherish the traditional coworker model as much as possible. The mistake is the either/or thinking that assumes that just because lifesharing is holistic, employment cannot be. After all, there are viable-albeit far from perfect-models for work that 
is both paid and holistic in the larger society. In my experience, the roles of the university professor, the parish minister, and the family farmer are all defined in primarily holistic terms. Many anthroposophical initiatives that do not practice incomesharing are also intentional about cultivating a holistic understanding of their employees' roles. Camphill, in short, is well-positioned to reimagine employment in more holistic terms, if it were to make that a priority.

One reason that Camphill has not defined employee roles more holistically is that Camphillers are reluctant to impose aspects of Camphill life that are connected to anthroposophy on people who have not freely chosen anthroposophyyet it remains the case that there is an implicit expectation that villagers and young coworkers will participate in such activities, while employees will not. Whether the "opt-in" or the "opt-out" approach is more respectful of persons' spiritual freedom, it would seem logical to apply the same standard to all three groups, since all three typically come to Camphill without a personal commitment to anthroposophy. Another factor is that long-term coworkers are often appropriately aware of their own lack of insight into the employee experience, since many of them have never worked eight-hour, five-day jobs. But this is just to say that Camphills must find new ways to incorporate employees into decision making and into the long-term visioning process of the movement.

When I have raised this point, many Camphillers respond that employees do not want to take on leadership roles, cannot afford to be away from their families to participate in festivals, and so on. In part this is a result of recruitment strategies: if enthusiasm for festivals is not a criterion in hiring, it is not surprising that many employees lack enthusiasm for festivals. And it is certainly true that Camphill festival practices and decision-making structures, as they currently exist, are not very convenient for persons who have their own families and households and may live at a distance from Camphill. But this is just to say that Camphillers have not prioritized the full inclusion of employees in community life to the same extent that they have prioritized the full inclusion of persons with learning difficulties.

A final factor that limits employees' gifts to the Camphill Movement is the fact that they very seldom participate in it beyond their local community. At Glencraig, for example, Tracey McCoubrey told me that she felt empowered to participate in some larger events after she completed the seminar, but that other staff "sometimes don't feel that they have the support to do so." She also reported the poignant experience of attending a training at Camphill School Aberdeen and learning that people there used the term coworker to include everyone, both employees and lifesharers. She came back with renewed determination to promote more inclusive language at Glencraig. ${ }^{147}$

Fran Pioli, the Cherry Orchards employee who reported that she was fully included in all aspects of life in her own community, also said that when she attended a series of retreats on "Camphill essentials" that brought together people from many places, she was the only employed person there. The rest were all 
incomesharing coworkers from villages in rural areas. "I was the only thorn in the side of all things Camphill," she said, then clarified that this was mostly a joke. Everyone at the retreat embraced her with the same openness that she had always felt at Cherry Orchards. Still, it was significant to realize that other Camphills were not necessarily pushing their employees into leadership in the movement as a whole, and she continued to think of herself as "a Cherry Orchards coworker rather than a Camphill coworker." ${ }^{148}$

As far as I have been able to determine, employees who choose to participate in Camphill activities beyond their local communities are welcome to do so. In many cases, they are invited to participate; in some cases, their communities provide financial support for their participation in much the same way they might do for coworkers. It is, however, extremely rare for participation in the larger movement to be a mandatory part of the job description of a Camphill employee. Granted, it is not a mandatory part of the job description for coworkers either, but-especially for coworkers who join the inner community-it is a strong implicit expectation, and in any case coworkers do not work with such formalized job descriptions as employees do. Thus, many coworkers feel that they are needed by the Camphill Movement as a whole, while employees almost never feel this.

This may be the real barrier to full inclusion of Camphill employees. Employees, by and large, do not engage with the larger movement because so many coworkers do. If Camphill had been established on the basis of employment from the beginning, a subset of employees would naturally have gravitated to the regional and international organizations. They would have become the people leading Camphill into the future. (This is, for the most part, the pattern in the L'Arche movement, because that movement's preference for assistants who are single has greatly limited the pool of assistants who make lifelong commitments. Thus, nonresidential employees-some of them former assistants-dominate movement leadership.)

In somewhat different words, Camphill's current challenge is to recognize employees as an essential organ within the organism of Camphill. Too often, they are implicitly imagined to be more like a crutch or wheelchair-something that may be useful or even necessary, but not truly part of the organism. In the past, employees were chosen precisely to be exceptions, to do things that other Camphillers were unwilling or unable to do. Now that they are such a large component of the Camphill organism, they must be treated as Camphillers, from the way they are chosen to the way they are trained to the way they are invited to participate in shaping Camphill's future both locally and internationally.

In arguing for a more inclusive and holistic approach to Camphill employees, I am not at all suggesting that those Camphills that seek to maximize the number of lifesharing coworkers and to minimize the number of employees are in the wrong. If Camphill follows the developmental path of creative symbiosis, the number of employees may stabilize and the number of lifesharing coworkers increase-just as if it follows the path of evolving beyond community, employment may continue 
to grow as lifesharing disappears. Both developmental paths could bring significant benefits, and I am inclined to suspect that the movement will thrive best if different communities take different paths. But even in the model of creative symbiosis, employees will have important roles to play. They may well be the catalysts who help outsiders become invested in Camphill's communal values. So Camphill can only benefit from greater thoughtfulness about how to include employees in its future.

\section{PARENTS}

Employees, as the previous section has made clear, are the most controversial Camphill constituency, the group that has generated the most heated debate within the movement. There is no comparable debate about parents and other family members of Camphill students and villagers. Yet their role within the Camphill Movement has changed almost as dramatically as that of employees, and in a similar way. Early on, they were peripheral to the Camphill organism. They played a functional role without being invited to shape Camphill's future. Today, they are more physically present and emotionally connected to Camphill communities. Many yearn to be active partners with other Camphillers in shaping the future. Yet the movement has not yet evolved the structures needed to maximize parents' contributions.

Some Camphill historians have suggested that the founders sometimes mirrored the attitudes of the larger society in their negative view of the parents of persons with intellectual disabilities. Rudolf Steiner, in his course on curative education, traced the disabilities of some children to their parents' life choices. One boy, Steiner said, had trouble learning language because his mother's career as a stage actor had put "a considerable strain" on her astral body, which in turn inhibited the development of his own astral body. Another boy's challenges began because his mother felt so healthy during pregnancy that she was reluctant to give birth, especially after the sudden death of the child's father. Steiner did not tell these stories in a punitive spirit, but with a sensitivity for the complex subjectivity of the two mothers. His larger point was that everything is interconnected and thus worthy of attention in a holistic educational approach. ${ }^{149}$ The stories nevertheless validated the belief that children who struggled in their home context would benefit from being placed in an entirely new environment. By structuring their community as a boarding school, Camphill's founders implicitly promised that they could empower children with special needs more fully than parents could. They interpreted subsequent experiences in ways that confirmed this premise. The early records of Camphill School are filled with complaints about the regression and disruption that occurred when students made too frequent or too lengthy visits home..$^{150}$ I have occasionally heard similar complaints about parents in Camphill communities of the twenty-first century. 
These negative attitudes coexisted with significant cooperation between parents and Camphill. The Macmillans were extraordinarily generous to the budding movement, and in future years other families would exhibit similar generosity. Parents were crucial to Camphill's very survival as a German-rooted movement planted in the soil of World War II Britain. They "formed the outer ring of the community," one Camphiller told me. They weren't especially visible, "but they were the ones who would speak up" for the radical ideal of "education for everybody." 151

At least a few parents moved from the outer ring to the inner circle of Camphill. In 1959 Meg Farquhar, whose marriage was failing, took a job in the Murtle House laundry at the same time as her ten-year-old son Alistair enrolled as a day student at St. John's School. Alistair, according to Meg's obituary, "was born . . . with a frail constitution but with a capacity for sparkling joy and special forces of the heart." A year later, Meg became a Camphill coworker and Alistair a residential student. During her years at Camphill School, she served as both a teacher and housemother and became "renowned for giving guidance to the most challenging children and co-workers." She cofounded the Aberdeen Waldorf school. Both she and Alistair then spent the final years of their lives as part of the Newton Dee village community. ${ }^{152}$

As the Camphill Movement expanded, the parental role in fundraising also expanded. Not every Camphill parent has a Scottish estate to offer, but many have more than the average share of wealth and social connections. The benefit calendar of Camphill Village USA in Copake, New York, is a testament to the social capital of its parents. The Anne Ratner Concert Series, now in its forty-third year, features home concerts by many of New York's most prominent classical musicians. Initially these were in the home of Ratner herself; since her death, they have been continued by other families with Camphill connections and the wherewithal to turn their homes into music venues. ${ }^{153}$ The Joseph D. Freedman Bowl-a-Thon, similarly, "is the brainchild of the siblings of Susie Freedman, who has lived at Camphill since 1977." "154 "Families and friends" organizations play a leading role in fundraising for most Camphills, and several Camphill communities were first founded through the organizational efforts of parents.

Camphill Glencraig in Ireland used the occasion of its twenty-first anniversary in 1975 to expand its engagement with parents, hosting a series of conferences specifically for parents as part of a broader effort "to open its gates widely to the world."155 For many of the participating parents, this was a rare opportunity to "openly talk about their problems and their experiences to us [coworkers] and to each other." For the coworkers, it was a chance to break out of old prejudices against parents; as one reported, "it was a humbling experience to be allowed to witness the searching, the devotion and the triumphs of the guests who were with us and I felt that by coming here they were entrusting us with something precious: themselves, as well as their children, which we must try to be worthy of." 156 
When parents help Camphill communities raise funds, and even when they serve on their governing boards, their role in the movement can remain functional. Many parents hope to ensure that their children will always have a safe and stimulating place to live, but do not care whether that place will be structured as an intentional community, whether it will have a cooperative economy and a sustainable ecology, or whether it will draw spiritual sustenance from anthroposophy. As coworker Andrew Plant put it, "the parents of some of the residents of Camphill just cannot express their thankfulness and gratitude enough," but they also treat Camphill as a sort of "black box." "I have no idea what's in that box," they say. "I don't need to know, don't even try to tell me. I like what comes out of it." ${ }^{157}$

A few of the Camphill places I have visited have begun to evolve a more holistic way of connecting with parents. I have rarely visited Heartbeet Lifesharing without spending time with at least one parent. I have harvested crops alongside a retired Ivy League professor whose son lives in the community, and sung South African freedom songs under the direction of that same villager's mother. The community's longest-serving employee is a parent whose confident, outgoing daughter gives the lie to old prejudices about parents as a threat to their children's self-development. And the last time I attended a Camphill youth conference at Heartbeet, I was surprised to notice a large contingent of participants in their sixties. Heartbeet had invited its list of parents to the conference, as well as coworkers from across the region. The conference was designed to offer a holistic engagement with Camphill's traditions-with workshops on eurythmy, social threefolding, anthroposophical speech, biographical work, "nature sculpture," and clowning-and the parents were clearly motivated by a desire to enrich their own lives, not merely to check up on their children. Some brought friends along with them, further widening the symbiotic circle of people invested in Heartbeet's future. And when Heartbeet sent a large contingent to an international Camphill festival in Germany, that group included parents as well as coworkers and villagers.

The dynamic is similar at Cascadia, which is located in an urban neighborhood in North Vancouver and includes many day-program participants who live with their parents. Parents participate in daily work shifts in the garden and craft studios, and there is a regular gathering of parents who discuss topics ranging from social care policy to anthroposophical spirituality. As a relatively small, urban Camphill, Cascadia is invested in building deep relationships with all of its neighbors, and the parent group is central to their strategy for making that happen.

At Botton Village in England, parents embody Camphill's move toward creative symbiosis in a more activist way. For the past several years, Botton has been locked into a difficult struggle between the governing board of Camphill Village Trust, which favors the developmental path I have named as "evolving beyond community," and a group of long-term coworkers committed to traditional practices of incomesharing and lifesharing. In 2014, parents of Botton villagers played the leading role in organizing Action for Botton. This group raised funds, organized 
petitions, and sought out sympathetic press coverage for the coworker group, ultimately enabling them to reorganize a segment of the village as the Esk Valley Camphill Community. ${ }^{158}$ They serve as a model for parental activism at other places experiencing conflict over Camphill's future. At the same time, parents play prominent roles in many of the Camphill boards that have pushed the movement to evolve beyond community.

\section{BOARD MEMBERS}

Nonprofit boards exercise ultimate legal authority over most Camphill places. When Camphill was founded, it was assumed that boards would mediate between Camphill and the larger society, ensuring good relationships with social care authorities and a steady stream of donations and government funding, while leaving real decision-making power in the hands of long-term coworkers. The first time I attended a meeting of the Camphill Association of North America board, its chair encapsulated this view of the board's role. Alluding to the use of cosa nostra, or "our thing," to describe the Sicilian mafia, he told the gathered coworkers that he thought of Camphill as "cosa vostra"-your thing. Whatever the merits of this approach, it has eroded in the face of multiple crises in recent decades. Boards carry a legal, fiduciary, and ethical responsibility for the integrity of the organizations they serve, and in times of crisis they rightly refuse to delegate that responsibility. The question then becomes whether they will work to restore the integrity of the Camphill place in all its facets, or whether they choose to sacrifice certain aspects of Camphill life. Specifically, is it right to sacrifice the values of incomesharing, lifesharing, or collective leadership in order to preserve Camphill's status as a social care provider sanctioned by governmental authorities? The answer to this question often hinges on how the mission of Camphill is formally defined in its governing documents, on the background and values of board members, and on how their responsibilities were described to them when they were recruited.

Until recently, virtually all Camphill places were incorporated as "charities" or "nonprofits" in accordance with the laws of their host countries. In other respects, though, their board structures are diverse. In two nations, Norway and the Republic of Ireland, a single charity is responsible for all the Camphill places in the country. These charities are modeled on the Camphill Village Trust, which was initially created to administer Botton Village and then took on responsibility for planting additional villages and town communities in England, Scotland, and Wales. Its size is similar to the Irish and Norwegian charities, though it includes only about half of the Camphill places in England and Wales and no longer includes any Scottish communities. The constituent communities of these three large charities typically have their own local committees whose authority is subordinate to that of the overarching charity. Most other Camphill places-certainly those in the United States, Canada, Scotland, Northern Ireland, and Germany-are incorporated 
individually. They participate in umbrella organizations with their own boards, such as Camphill Scotland and the Camphill Association of North America. But in these cases it is the umbrella organization whose authority is subordinate to that of the individual Camphill places.

Camphill boards differ on whether it is appropriate for residents of Camphill to serve as board members. Many nations have laws prohibiting employees of charities from serving on charitable boards, or limiting the number of employees who can serve. It is not always clear whether these statutes apply to incomesharing coworkers. Thus, while from the outside it may appear that different Camphill boards have made different choices about whether and how to include coworkers (or employees or villagers), from the inside many boards believe that they do not actually have a choice at all, but have done what they are legally obligated to do. And some are simply confused: when I interviewed one coworker in 2015, he told me that he had recently been asked to join his community's board, then told at his first meeting that he was not eligible to serve. But when I followed up three years later, he informed me that he was ultimately able to join the board, since the community was not able to confirm the legal objection. They wound up deciding that a "representative minority" of coworkers on the board was "both welcome and necessary." 159

Though the composition of many Camphill boards has changed radically in the past few years, the fact of diversity is not new. In 1975, for example, one Camphill in Switzerland had a formal agreement in which the coworkers' group chose half plus one of the board's members and the parents' group chose the remainder. Another Camphill, also in Switzerland, had a board composed entirely of people from outside Camphill. ${ }^{160}$ (Perhaps not coincidentally, the latter community withdrew from the Camphill Movement in 1995.)

In the UK, the prevailing legal opinion is that at least 50 percent of the members of a charitable board must be "completely external," with coworkers, employees, villagers, and parents all classified as internal. It was a "game changer," one person told me, when that policy was clarified, because it meant that "if you didn't have enough time to recruit the right people," the external members "could suddenly turn the whole organization upside down." ${ }^{161}$ The Camphill Village Trust, for example, has responded to this policy by recruiting a board with three parents or family members of villagers, five people with extensive background in the social care establishment, and no coworkers or persons connected to anthroposophical initiatives. ${ }^{162}$ Other Camphill places in the UK have made radically different choices. During my visit in 2013, several people described Gannicox and Cherry Orchards as the two English Camphills that were most committed to traditional governance by coworkers, but their boards were quite different. Gannicox had received what they called an "extremely benevolent" legal judgment that allowed them to constitute a board with three coworkers, alongside a retired anthroposophical doctor, a retired Waldorf teacher, a coworker from another Camphill, 
and a retired therapist. ${ }^{163}$ Cherry Orchards, by contrast, had no coworkers on their board, but had also resisted relying on the mainstream social care establishment: their board included a retired psychiatrist, a former parent, and a former villager, among others. "They are actually people who understand what we are doing," explained Stephen Sands, "and we educate them also in anthroposophical thought processes, so they can think with us."164

When I visited several Irish Camphills in 2013, I was told that the Council of Camphill Communities of Ireland was undergoing a dramatic transformation. Historically, it had included one representative from each community, along with a few outsiders. Also historically, the community representatives had been coworkers, though by 2013 a few were employees instead. But this structure was judged to be too large, so they made a separation between a small council and a larger "neighborhood" in which each community would be represented. ${ }^{165}$ In 2018, the council had just seven members. According to the biographies published on the CCI website, two had careers in mainstream social care, one had a background in academia and environmentalism, three were parents of villagers, and one was a lifesharing coworker. ${ }^{166}$

The Camphill Village Trust in Norway has also wrestled with the question of how to represent all its communities without creating an unmanageably large board. As of 2016, each community had a village council composed of long-term coworkers. The charity, in turn, had a "council of representatives," chosen by the individual villages, with a guaranteed majority of coworkers serving alongside "representatives from a Camphill overseas" and "prominent figures in Norwegian society." This council of representatives, however, is not the governing body: its role, in addition to discussing issues in a general way, is to appoint a smaller statutory board for the charity. This board also has a mandated balance of Camphillers and outsiders. ${ }^{167}$

The board of Camphill School Aberdeen includes a social work professor who encountered Camphill through the BA program, an anthroposophical doctor who works in the Camphill clinic, a coworker at Newton Dee, and at least three parents or family members. ${ }^{168}$ As an umbrella organization, Camphill Scotland has a twelve-member council in which eleven trustees are nominated by the eleven constituent communities (resulting in a mix of coworkers, employees, and board members), while the chair is recruited from beyond Camphill. ${ }^{169}$

In the United States, it is rare or nonexistent for coworkers to constitute the majority of a board, but they are typically represented and together with parents they may constitute a majority. The bylaws of Soltane stipulate that at least 25 percent but no more than 50 percent of board members must be coworkers. ${ }^{170}$ At the time of my visit in 2014, Kimberton Hills recently softened a long-standing practice of maintaining a fifty-fifty balance between residents and nonresidents on its board, but it still had four residents on the board, along with one Camphiller from another community, one other committed anthroposophist, a doctor with 
connections to anthroposophical medicine, a Waldorf parent, a Camphill parent, and a few people with business skills but no deep connection to either Camphill or anthroposophy. ${ }^{171}$ It is also common for boards in the United States to defer to the internal leadership structures of the communities. At Beaver Run Carsten Callesen told me, "We do the prep work and we are well prepared. We go through processes before we bring it to the board. They may still ask questions, but they tend to have a strong faith in us that we know what to do and we know what we want and it is financially sound." ${ }^{172}$ Diedra Heitzman of Kimberton Hills similarly said, "We are not a start-up place and we are not at this point yet dying or transforming in that way. The board has felt fairly confident with what we've been doing, and very supportive.... We are making a lot of internal decisions that they agree to, but they also have the possibility to envision things and turn us in a direction that they feel we should go in." ${ }^{173}$ And the Soltane board, I was told, is trying to envision itself as a stakeholder board in which "everyone who is impacted by the community or part of the community has a voice in the governance of it." The stakeholder groups include students, their families ("which are two different stakeholder groups"), coworkers, employees, public officials, people who work in the field of social care, people who support Camphill "just because," and ("the only other stakeholder group that we haven't tapped into yet") customers of Camphill businesses. ${ }^{174}$

One practice that is widespread in North America and Scotland but virtually nonexistent elsewhere is that of inviting coworkers to serve on the boards of Camphills other than the ones where they live. Beaver Run and Soltane, for example, have a long-standing tradition of having representatives on one another's boards-a practice that has helped them maintain open lines of communication even as they have taken divergent positions in the debate over the use of employees. For many years, Camphill Minnesota had a board member who lived at Community Homestead, a village similar to Camphill though not formally affiliated with the movement. The Camphill Association of North America has even contemplated mandating that all of its constituent communities must have other communities represented on their boards. ${ }^{175}$

When I have asked Camphillers in other parts of the world why they do not do this, I have received a variety of answers. Stephen Sands said it was impossible to recruit Camphillers from other places because "people are just overdone," but noted that they did have representatives of other anthroposophical initiatives. ${ }^{176}$ There is an obvious challenge for the Irish and Norwegian charities, which would have to seek such representatives from beyond their national borders-though I must note that the driving distance from the Camphills in northern Ireland to those in the republic is about the same as that from Camphill Village Minnesota to Community Homestead. It is also the case that there are relatively few other anthroposophical initiatives in Ireland from which board members might be recruited, and some of these receive financial subsidies from Camphill. ${ }^{177}$

Camphills in North America have taken significant steps to incorporate villagers and other persons with learning difficulties into board governance. When I 
spoke to folks at Kimberton Hills in 2014, they did not mention having any villagers on the board, but the published list in 2018 included one villager, who was also identified as a "self-advocate." ${ }^{178}$ Camphill Copake's board also has one villager. Leaders at Soltane (a training college) told me that former students have served on their board almost from the beginning. "It has been an intention and actually for many years we have supported the people on our board and on the association board. . . . It is really something, how to make this process of inclusion real." Through their connection to the self-advocacy group Speaking for Ourselves, "we have a very educated group of people that is pretty strong and wanting to speak for themselves, or wanting to hold these advocacy roles." ${ }^{179}$

Currently, some Camphillers are asking whether incorporation as charities is the right structure for a communal movement. Ordinarily, a charity is accountable to its mission, not to its members, and for this reason charitable boards are usually self-perpetuating rather than elected. Arguably, an intentional community that is the home and workplace for a specific group of people should be governed more democratically. Some Camphillers, notably Andrew Plant in Scotland, have urged the movement to pay close attention to the cohousing movement, which has developed strategies to allow large groups of people to own property together and govern themselves democratically. ${ }^{180}$ Others have considered reorganizing as cooperatives or "benefit corporations" (that is, for-profit entities with a social mission). To my knowledge, the one Camphill communities that has embraced such a structure is Gannicox, a small community in England that is a hybrid of a town community and an elder community, and also sponsors a clinic and a kindergarten. In 2014, Gannicox's coworkers organized themselves into a Community Interest Company (the British equivalent of a benefit corporation), which allowed them to designate themselves as the sole directors. The Gannicox CIC contracts with the local county council to provide social care and support to residents with disabilities. Meanwhile, the original charity (called St. Luke's Trust) remains the landlord and maintains tenancy agreements with both the villagers and the members of the CIC. This arrangement fits well with British social care policy, which encourages persons with special needs to make separate arrangements for their housing and their care (in the interests of individual freedom). It also grants the coworkers partial autonomy from external boards, while ensuring their accountability to social care authorities. Though this plan is quite creative, its intent is simply to safeguard Gannicox against heavy-handed board governance. "It is hard," its architect wrote to me in the message announcing the change, "not to be gloomy about the outer shell of Camphill over here."181

Ultimately, the governance of a healthy organization should mirror its structure, with all constituencies represented and all representatives sufficiently connected to the organization as a whole that they will make holistic decisions rather than narrowly promoting the interests of their constituencies. Yet for most of Camphill's history, decision-making power has been concentrated in an unbalanced way among just one constituency, that of the lifesharing coworkers. Camphill boards 
began as auxiliaries to the coworker group and evolved into counterweights to that group-sometimes balancing coworker perspectives in a harmonious way and sometimes actively opposing the coworkers. The current developmental task of Camphill boards is to evolve beyond that polarity and become authentic meeting places for all Camphillers.

In many ways, the developmental task for Camphill boards is the same as the task for the Camphill Movement as a whole: how can it evolve beyond its coworker-centered beginnings so that all constituents can come together in the work of shaping Camphill's future? If this evolution is to succeed, a new and creative conversation is needed between Camphill's governing boards and the Camphill inner community. From one perspective, their roles are similar: both are located at a remove from Camphill's day-to-day work and charged with ensuring its overall integrity. From another perspective they are sharply differentiated, since the inner community focuses on the spirituality of Camphill, while board responsibilities center on finances, laws, and other outer structures. Their composition is also dissimilar: everyone in the inner community has a personal connection to anthroposophy and most have spent a decade or more living in Camphill, while relatively few board members have lived in Camphill or practiced anthroposophical spirituality. Since both have significant power to shape Camphill's future, the possibility for tension and misunderstanding is great.

One such tension erupted at a 1991 gathering of the inner community's "Movement Group," when board members were invited to the gathering but excluded from a few sessions. They complained, provoking a series of conversations that led the "Movement Group" to "become free of its former task as a Community organ" in $1995 .{ }^{182}$ In other words, the Movement Group was now in a position to bring all of Camphill's stakeholders together for conversations about the future of Camphill, and in particular to mediate the ongoing tensions between boards and inner community. But this shift did not clarify the mandate of either the inner community or the Movement Group. Currently, the Movement Group is governed by a document, prepared in 2016, that identifies it as a "non-executive organ of the Camphill Movement" and places primary emphasis on such tasks as "networking," "vision building," "active exchange, interaction, and communication," and "rais[ing] consciousness." It repeatedly names the inner community, the "international dialogue," and the Camphill regions as other organs that will be involved in Movement Group conversations, along with the Anthroposophical Society and its School of Spiritual Science. But Camphill governing boards are nowhere mentioned in the document. ${ }^{183}$

Thus, Camphill's evolution continues to move on separate tracks. Those governing boards that are most inclined to evolve beyond community are minimally engaged in the international conversations sponsored by the Movement Group, while the international bodies most committed to lifesharing and incomesharing are disproportionately dominated by coworkers. Governing boards and lifesharing 
coworkers hold vastly more formal power than other Camphill constituencies. To the extent that the two powerful groups remain polarized against one another, there is little prospect for genuine empowerment of the other constituencies. Yet when boards and coworkers are genuinely able to come together, there is real potential for all the constituencies to join in turning the movement to the path of creative symbiosis. That symbiosis will, in turn, involve new forms of interaction with the many contexts that have shaped Camphill's evolution thus far. 